\title{
Politika optimismu a opatrnosti
}

\author{
Moskva a východní Evropa na konci 80. let
}

\author{
Alex Pravda
}

Během převratných změn roku 1989 ve východní Evropě působila Moskva dojmem blahosklonného přihlížejícího. Zdálo se, že Kreml flegmaticky přijímá zhroucení uspořádání, které v oblasti po druhé světové válce sám vybudoval a které pomáhal následující čtyři desetiletí navzdory mnoha krizím udržovat. Přesun z pozice konzervativního strážce sovětského pořádku $\mathrm{v}$ tomto regionu do pozice liberálního podporovatele radikální reformy byl asi tím nejvýznačnějším ze série dramatických obratů, které v letech perestrojky zcela proměnily zahraniční politiku Moskvy. Nový, liberální př́stup ke změnám $\mathrm{v}$ komunistickém bloku byl nejdůležitějším faktorem, který přispěl ke konci studené války v Evropě. I pokud nahlížíme na zhroucení komunismu ve východní Evropě především jako na výsledek intenzivního tlaku občanské společnosti a nedostatečné reakce vládnoucích elit, Moskva se zásadním způsobem podílela na obou těchto jevech. Některé z událostí, jež Sovětský svaz svým př́stupem umožnil, byly odrazem nových priorit Kremlu. To, k čemu v roce 1989 došlo, bylo však z větší části nezamýšleným důsledkem politiky, která měla původně pomoci vybudovat rovnoprávnější a soudržnější socialistické společenství.

Tato studie nemůže vzhledem ke svému omezenému rozsahu zhodnotit komplexní, často nepřímý a nezamýšlený příspěvek Moskvy ke změnám roku 1989. ${ }^{1}$ Omezím

1 Výbornou analýzu sovětské politiky a s ní souvisícího vývoje lze nalézt ve studiích: LEVESQUE, Jacques: The Enigma of 1989: The USSR and the Liberation of Eastern Europe. Berkeley, University of California Press 1997; KRAMER, Mark: The Collapse of East European Communism 
se proto na náčrt obrysů nových politických priorit Kremlu a nabídnu možná vysvětlení, proč byly tyto priority stanoveny. Ve druhé části studie pak ukáži, jak se tyto priority promítly do utváření principů, na jejichž základě se Moskva prakticky zapojovala (či stejně tak často vyhýbala zapojení) do politického vývoje v oblasti. Zastávám přitom tezi, že hlavním důvodem pro změnu její politiky byla snaha odpoutat se od tradičního modelu závislosti a dominance ve vztazích se zeměmi východní Evropy. Toto rozhodnutí bylo založeno především na novém zhodnocení nákladi̊ a zisků starého vztahového modelu v materiální a mocenské rovině. Přechod k novému vztahovému rámci pak poháněly ideje, totiž klíčová východiska „nového myšlení, zvláště pak víra v modernizaci pod vedením komunistické strany a principiální odpor vi̊či užití násilí. Tato myšlenková východiska, v nichž se odrážel a zároveň spojoval a mísil optimismus s opatrností, byla charakteristická pro reakci Moskvy na rychle se měnící politickou situaci ve východní Evropě v letech 1988 a 1989.

\section{Politické cíle a priority Kremlu}

Cíle Gorbačovovy východoevropské politiky měly zřetelněji vymezeny spíše negativní než pozitivní kontury. Sovětský vládce dával jasně najevo, a to jak v soukromí, tak na veřejnosti, že chce skoncovat se starým př́stupem k východní Evropě jako ke skupině závislých států. ${ }^{2}$ Obecně se rozhodně chtěl ubírat směrem k větší rovnoprávnosti ve vzájemných vztazích. Vztahový a institucionální rámec v představách Kremlu byl ovšem definován jen vágně. Gorbačovův tým chtěl vybudovat vztahy založené spíše na svobodné volbě než na vnucené poslušnosti. Východoevropské státy, jak Gorbačov stále častěji od poloviny roku 1988 zdůrazňoval, nyní měly mít skutečnou svobodu volby ve svém dalším směřování. ${ }^{3}$ Kremelská vize nového mode-

and the Repercussions within the Soviet Union, 1-3. In: Journal of Cold War Studies, roč. 5, č. 4 (2003), s. 3-42 (1. část); roč. 6, č. 4 (2004), s. 3-64 (2. část); roč. 7, č. 1 (2005), s. 3-96 (3. část).

2 Gorbačov o tom hovořil velice př́močaře na jednání politbyra ÚV KSSS 3.7.1986 (viz $V$ Politbjuro TsK KPSS... Po zapisjam Anatolija Čerňajeva, Vadima Medveděva, Georgija Šachnazarova (1985-1991). Moskva, Alpina Biznes Buks 2006, s. 61). Krátce předtím Gorbačov shrnul své úvahy v šestistránkové zprávě pro politbyro (viz Hoover Institution Archives (Stanford), Volkogonov Papers, R10049, O někotorych aktualnych voprosach sotrudničestva so stranami, 26.6.1986). Ve svých pamětech hovoří o tom, že tato zpráva pocházela z května 1986 (viz GORBAČOV, Michail Sergejevič: Žizň i reformy, sv. 2. Moskva, Novosti 1995, s. 315; v českém překladu př́slušných pasáží Gorbačovových pamětí viz PREČAN, Vilém (ed.): Svědectví o rozpadu „socialistického společenství: Ukázky z memoárů Michaila Gorbačova, Vadima Medveděva a Valerije Musatova. In: Soudobé dějiny, roč. 5, č. 4 (1998), s. 509-554, zde s. 517).

3 Např́íklad v projevu předneseném ve Varšavě 11.7.1988 (viz GORBAČOV, M. S.: Sobranije sočiněnij, sv. 11. Moskva, Ves Mir 2009, s. 302-306; v českém znění: Projev Michaila Gorbačova v polském Sejmu. In: Rudé právo (12.7.1988), s. 6) či v projevu v Kyjevě 23.2.1989 (TÝŽ: Sobranije sočiněnij, sv. 13. Moskva, Ves Mir 2009, zvláště s. 287 n.). 
lu vztahů však stále počítala se zásadním omezením sebeurčení jednotlivých států. Zachování Varšavské smlouvy zůstávalo jedním z ústředních předpokladů Kremlu téměř až do poslední chvíle. Tato vojensko-politická organizace se samozřejmě měla proměnit $\mathrm{v}$ jakousi dobrovolnou koalici, $\mathrm{v}$ alianci založenou minimálně na sdílených bezpečnostních zájmech, $\mathrm{v}$ ideálním případě pak na socialistických hodnotách. V představách Kremlu se formálně existující socialistické společenství mělo stát společenstvím opravdovým, sestávajícím z vojenské aliance a hospodářského bloku.

Nebyly to pouze obrysy tohoto „spojenectví-společenstvi“, které byly jen velice nejasně načrtnuty. Stejně nejasná zůstávala role Sovětského svazu v jeho rámci. I v tomto případě bylo opět nejzřetelněji vymezeno to, čemu se Kreml chtěl vyhnout - tedy prosazování vůle Moskvy prostřednictvím neustálého vměšování a občasných mocenských zásahů. V praxi to znamenalo opuštění tradiční vůdčí role Moskvy v oblasti. Mnohem méně zřejmé však bylo, čím chce Moskva toto uspořádání nahradit. Jestliže tvrdou kontrolu měly nahradit ohleduplnější konzultace na vyžádání, znamenalo to, že namísto vnucování vedoucí role Sovětského svazu státům východní Evropy pod pláštíkem zájmů „mezinárodního proletariátu“ měly tyto státy dobrovolně přiznat Moskvě pozici, která jí př́íslušela coby nejstaršímu členu společenství.

Obecně lze však konstatovat, že i když obrysy této vize nebyly ze strategického hlediska jasně definovány, samo rozhodnutí odpoutat se od starého modelu vztahů bylo důležité a význačné. Jak můžeme tento významný posun v cílech a prioritách vysvětlit?

\section{Materiální a mocenské faktory}

Z materiálních faktorů, které přinutily Kreml ke kritickému přehodnocení jeho východoevropské politiky, byla nejzásadnější a dlouhodobě nejtíživější otázka ekonomických nákladů těchto vztahů. Ekonomickému aspektu sovětských vztahů s východoevropskými státy dosud nebyla věnována pozornost, kterou by zasluhoval. ${ }^{4}$ Cena spojená s jejich zásobováním dotovanou energií byla v Kremlu dlouhodobě zdrojem podráždění, za Gorbačova se pak stala terčem stupňujících se stížností. Když vedoucí východoevropští představitelé žádali od Kremlu pomoc při odvrácení nestability, Gorbačov zaujal obzvláště tvrdé stanovisko. Řekl jim, že Moskva je již nemůže dál zachraňovat a že musejí najít cestu ven z krize sami. ${ }^{5}$ Tato ne-

4 Existuje několik užitečných studií, viz např. STONE, Randell W.: Satellites and Commissars: Strategy and Conflict in the Politics of Soviet-Bloc Trade. Princeton (New Jersey), Princeton University Press 1996; REISINGER, William M.: Energy and the Soviet Bloc: Alliance Politics after Stalin. Ithaca (New York), Cornell University Press 1992.

5 Viz Gorbačovův rozhořčený komentář na schůzi politbyra ÚV KSSS 30.10.1986 (GORBAČOV, M. S.: Sobranije sočiněnij, sv. 5. Moskva, Ves Mir 2008, s. 149 a 151). Gorbačov krátce odbyl 
ústupnost odrážela jak měnící se ekonomickou situaci, tak reformní priority nového sovětského vedení.

Bilance ekonomických vztahů s východní Evropou se jevila stále nepříznivěji. Moskva nadále posílala do regionu levnou ropu a zemní plyn, za které dostávala stále více nekvalitního zboží. Když nejrozvinutější východoevropské státy zjistily, že vězí až po uši v dluzích vưči kapitalistickému světu, začaly vyvážet své nejlepší výrobky na Západ, což Moskvu

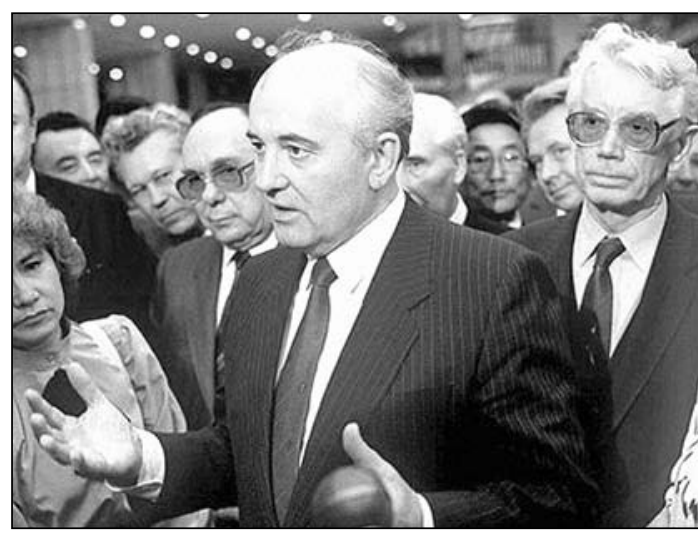

Michail Gorbačov a dva z jeho klícových spolupracovníků - Vadim Medvedèv (vpravo) a Alexandr Jakovlev (vlevo s brýlemi) silně dráždilo. ${ }^{6}$ Citlivost vůči takto se zhoršující obchodní bilanci byla o to silnější, že Gorbačovův tým si vzhledem ke svým vnitropolitickým prioritám mnohem zřetelněji než jeho předchůdci uvědomoval promarněné př́ležitosti, které byly spojeny s udržováním deficitního vztahu s východní Evropou. Aby bylo možné zvrátit úpadek sovětského hospodářství nastartováním programu radikálních reforem, bylo zoufale zapotřebí zdrojů. $\mathrm{V}$ této souvislosti je však nutné dívat se na ekonomické problémy, které východní Evropa přinášela, vyváženě - neznamenaly břemeno pro Sovětský svaz nadále již neúnosné, ale spíš nepřijatelné. Nebylo tomu tak, že by si Gorbačovův tým znenadání uvědomil, že region pro něj představuje neúnosnou ekonomickou zátěž, a proto by měl být odříznut a starat se o sebe dál sám. Spíš se dá ř́ci, že zhoršující se vzájemná obchodní bilance v kombinaci s naléhavými požadavky reformní agendy přivedla nové vedení v Kremlu $\mathrm{k}$ přehodnocení tradičních vztahů jako nepřijatelně nákladných.

Tento nový náhled Gorbačovova vedení byl ještě posílen tím, že se neztotožňovalo se svými předchůdci $\mathrm{v}$ ocenění bezpečnostních a politických mocenských faktorů, které dlouho pomáhaly vyvažovat ekonomickou ztrátovost bilance vztahů se státy východní Evropy. Pro Kreml, který se nyní pokoušel proměnit vztah se Západem z vojenské konfrontace na spolupráci, se jevila strategická hodnota tohoto vztahového modelu značně odlišně. Východní Evropu nepřestala Moskva pova-

i vůdce polských komunistů Mieczysława Rakowského při jejich setkání 21.10.1988 (viz TÝŽ: Sobranije sočiněnij, sv. 12. Moskva, Ves Mir 2009, s. 265).

6 Gorbačov si na schůzi politbyra ÚV KSSS 6.10.1988 stěžoval, že plná polovina obdržených výrobků z východní Evropy má nízkou kvalitu (viz tamtéž, sv. 12, s. 165 n.). 
žovat za strategicky důležitou, $\mathrm{v}$ souvislosti s novou agendou však přehodnotila bezpečnostní roli regionu a zmenšila jeho celkový význam. ${ }^{7}$ Moskva si historicky cenila východní Evropy hlavně jako obranného předpolí a předsunuté základny $-\mathrm{v}$ podstatě jako rozšíření sovětské bezpečnostní zóny. Poté co za Gorbačova zásadně přesunula důraz na odzbrojení jako cestu $\mathrm{k}$ zajištění vlastní bezpečnosti, se pro ni tato oblast stala předsunutou zónou určenou k redukci ozbrojených sil a budování vzájemné důvěry mezi Východem a Západem. Logická východiska nové bezpečnostní koncepce, jejímž cílem bylo postupně odstraňovat důvody pro existenci Severoatlantické aliance a Varšavské smlouvy, byla posilována ekonomicky motivovanou snahou snížit náklady na zbrojení. Jedním z výsledků byl návrh Moskvy z prosince 1988 na omezení konvenčních ozbrojených sil ve střední a východní Evropě (včetně stažení šedesáti tisíc z celkového počtu půl milionu vojáků rozmístěných v zemích Varšavské smlouvy). ${ }^{8}$

Citlivější vnímání nákladů při přehodnocování východoevropské politiky se projevilo asi nejvíce $\mathrm{v}$ úvahách o ozbrojených intervencích. Že za intervence jako způsob řešení zásadních krizí v oblasti platí z materiálního i politického hlediska vysoké náklady, si Kreml samožrejmě uvědomoval již před nástupem Gorbačova. Proto také váhal s nasazením vojenských jednotek již v roce 1956, a tím spíše pak v letech 1968 a 1981. Během vypjatých debat o Polsku na konci roku 1981 dokonce i zastánci tvrdé linie $\mathrm{v}$ sovětském politbyru vyjadřovali vážné pochybnosti ohledně vojenské intervence jako cesty k obnovení pořádku. Jurij Andropov, který stál v čele Výboru státní bezpečnosti (KGB), i hlavní ideolog režimu Michail Suslov argumentovali proti vyslání jednotek k potlačení Solidarity. ${ }^{9}$ Jejich zdrženlivý př́stup k nasazení síly za účelem obnovení „pořádku“ v Polsku ještě posilovaly pochybnosti o účinnosti sovětského zásahu v Afghánistánu. Již před nástupem Gorbačova se tedy smýšlení Kremlu začalo vyvíjet v neprospěch intervencí. To však neznamená, že by stará garda nebyla použila nátlakových prostředků (byt̉ možná ne př́mo intervence) $\mathrm{k}$ prosazení sovětských požadavků. Je těžké si představit, že

7 I opatrně uvažující mezinárodní oddělení UUV KSSS se domnívalo, že bezpečnostní „pás“ či ochrana, kterou státy Varšavské smlouvy poskytovaly, se musí proměnit (viz Memorandum from the International Department of the Central Committee of the CPSU to Alexander Yakovlev. In: Cold War International History Project Bulletin (dále CWHIP Bulletin), č. 12-13 (2001), s. 64; citovaný dokument pochází z února 1989).

8 Diskuse o těchto úvahách přibližuje memorandum Gorbačovova poradce Georgije Šachnazarova z 2.10.1989 (viz ŠACHNAZAROV, Georgij: Cena svobody. Reformacija Gorbačeva glazami jego pomosčnika. Moskva, Rossika 1993, s. 423-425).

9 Viz MASTNY, Vojtech: The Warsaw Pact as History. In: MASTNY, Vojtech - BYRNE, Malcolm (ed.): A Cardboard Castle? An Inside Story of the Warsaw Pact, 1955-1991. Budapest, Central European University Press 2005, s. 50-54; LOTH, Wilfried: Moscow, Prague and Warsaw: Overthrowing the Brezhnev Doctrine. In: Journal of the Cold War History, roč. 1, č. 2 (2001), s. $103-118$. 
by Andropov souhlasil, tak jak to udělal Gorbačov, s nastolením politického pluralismu v Madarsku či s nástupem vlády Solidarity v Polsku.

Gorbačovi̊v tým si z předešlých krizí odnesl poučení, že užití síly bylo nesmírně nákladným a neúčinným prostředkem $\mathrm{k}$ obnovení politického pořádku. ${ }^{10}$ Jakožto člen komise sovětského politbyra pro Polsko v letech 1980 a 1981 měl Gorbačov bohaté osobní zkušenosti, ze kterých mohl vycházet. Od svých předchůdců se zvláště výrazně odchyloval v názoru na použití síly samotnými východoevropskými vůdci za účelem obnovení jejich kontroly nad domácími politickými poměry. Sovětský vůdce jasně formuloval svi̊j odpor $\mathrm{k}$ užití nátlakových prostředků před všemi vedoucími východoevropskými soudruhy, kteří naznačili, že zvažují použití síly $\mathrm{k}$ upevnění své pozice během otřesů $\mathrm{v}$ roce 1989. A stejně jednoznačně dával najevo, že preferuje vstřícné politické strategie při řešení výzev, které nastolovala opozice.

Tyto nové preference tedy odrážely pragmatičtější zhodnocení sovětských zkušeností $\mathrm{s}$ východní Evropou Gorbačovovým týmem. ${ }^{11}$ Gorbačovovo odmítavé stanovisko $\mathrm{k}$ užití síly, at již v podobě vojenské intervence zvenčí nebo vnitřního násilného zásahu pod sovětskou patronací, je ve světle zmíněného přehodnocování materiálních a politických nákladů a zisků vcelku pochopitelné. $\mathrm{K}$ vysvětlení Gorbačovova odhodlaného odporu vůči nátlakovým prostředkům a intervencím je však třeba zaměřit pozornost také na jeho ideová východiska a zásady.

\section{Nové ideály a zásady}

Postoj Moskvy vůči intervencím byl založen na principech stejně jako na pragmatických úvahách. Za Gorbačovovým neoblomným odmítáním zvážit možnost užití nátlakových prostředků k vyřešení problémů ve východní Evropě v roce 1989 stál zásadní odpor vičči nasazení síly. Gorbačov měl s užitím síly morální problém - vyjma situací, kdy by užití síly zcela jistě vedlo k odvrácení krveprolití. ${ }^{12}$ Tento zásadový postoj odrážel poučení (a zároveň jím byl posilován), které Gorbačovův tým načerpal z předešlých sovětských intervencí ve východní Evropě i mimo ni. Postupné prozření v tomto směru tak do značné míry vedlo $\mathrm{k}$ tomu, že se odmítání intervencí a užití síly stalo ústředním východiskem Gorbačovova „nového myšleni““.

10 Viz ŠACHNAZAROV, G.: Cena svobody, s. 94.

11 Hoover Institution Archives, Volkogonov Papers, R10049, O někotorych aktualnych voprosach sotrudničestva so stranami (viz pozn. 2).

12 Viz GORBACHEV, M. S. - MLYNAR, Zdenek: Conversations with Gorbachev on Perestroika, the Prague Spring, and the Crossroads of Socialism. New York, Columbia University Press 2002, s. 127-132 (české vydání: GORBAČOV, Michail S. - MLYNÁŘ, Zdeněk: Reformátoři nebývají št́astni: Rozhovory o „perestrojce“, Pražském jaru a socialismu. Praha, Victoria Publishing 1995, s. 106-112). 
Druhou stranou protiintervenční mince byl nový, principiální závazek respektovat právo východoevropských států rozhodovat o svém vlastním osudu a spojeneckých vztazích. Vystoupením na podporu sebeurčení států východní Evropy Gorbačov zavrhl Brežněvovu doktrínu, která dlouhodobě kodifikovala tradiční podřízenost jejich národních zájmů principům „proletářského internacionalismu“, určovaným Moskvou. Nově nabytý respekt vůči národní svrchovanosti východoevropských států byl zasazen do rámce obecného závazku uznávat všeobecnou svobodu volby. I tato idea se stala ústředním východiskem „nového myšleni““, jak byl označován Gorbačovův doktrinální koncept změn v zahraniční politice. ${ }^{13}$

Nový důraz na univerzálně pojímanou národní svrchovanost odrážel víru, sdílenou Gorbačovovým týmem, v konkurenceschopnost zmodernizovaného socialismu. Výslovné zahrnutí východoevropských států do tohoto nově formulovaného konceptu sebeurčení odráželo důvěru, že tyto státy budou usilovat o podobnou modernizaci socialismu, jakou představoval proces perestrojky. Tato důvěra pak pro změnu vyjadřovala přesvědčení, že modernizace prostřednictvím radikálního reformního procesu pod vedením obrozených komunistických stran je přirozenou a zároveň nejlepší cestou vpřed pro všechny členy východního bloku. Skutečnost, že Gorbačovův tým uvažoval tímto zpo̊sobem, není nijak překvapivá - regenerace idejí komunismu a modernizace socialismu představovaly základní články víry, na nichž byl založen projekt perestrojky. Rozšíření platnosti metod perestrojky na zbytek socialistického společenství, i při obvyklém respektování národních kulturních odlišností, jen odráželo pevnost společného přesvědčení celého Gorbačovova týmu.

\section{Tvorba politiky a její kvalitativní úroveň}

Interpretace východoevropské politiky Sovětského svazu zatím stavějí převážně na materiálních a ideologických východiskách. Existuje však i další úhel pohledu, který rovněž pomáhá pochopit přístup Moskvy k tomuto regionu, a to zkoumání procesu tvorby politiky. Tento pohled nenabízí alternativní vysvětlení, ale užitečné doplňující vhledy do problému. Kritická hodnocení východoevropské politiky v podání bývalých úředníků obvykle poukazují na nedostatky v tvorbě politiky a je-

13 GORBACHEV, Mikhail S.: Perestroika: New Thinking for Our Century and the World. London, Collins 1987, s. 164 n. (české vydání: GORBAČOV, Michail Sergejevič: Přestavba a nové myšlení pro naši zemi i celý svět. Praha, Svoboda 1987, s. 146 n.). V soukromí Gorbačov od začátku zdůrazňoval, že by se mělo jednat o skutečnou politiku, nikoli pouze o propagandu, jak ukazují např. jeho poznámky na schůzi politbyra ÚV KSSS 3.4.1986 (viz TÝŽ: Sobranije sočiněnij, sv. 3. Moskva, Ves Mir 2008, s. 520). Ve svém projevu ve Štrasburku 7.7.1989 Gorbačov poprvé jednoznačně vztáhl tento princip na socialistické spojence (viz LEVESQUE, J.: The Enigma of 1989, s. 115 a 118 - viz pozn. 1). 
jím praktickém uskutečňování. ${ }^{14}$ I když tato kritika může občas plynout z jejich politického smýšlení, stojí za to zamyslet se nad tím, jak Kreml vytvářel a prosazoval strategie, které měly vést $\mathrm{k}$ přechodu od starého systému dominance $\mathrm{k}$ vizi společenství založeného na opravdovém spojenectví. Koncipování a implementace jakékoli transformační strategie jsou i za ideálních podmínek náročné. $V$ tomto př́padě to byl úkol obzvláště obtížný, vzhledem ke změnám $\mathrm{v}$ celém regionu i na domácí půdè. Podmínky, v nichž se tato politika tvořila, celou situaci dále zhoršovaly. Domácí i zahraniční tlak na Gorbačovův malý tým byl tak silný, že proces vytváření politiky byl zpravidla

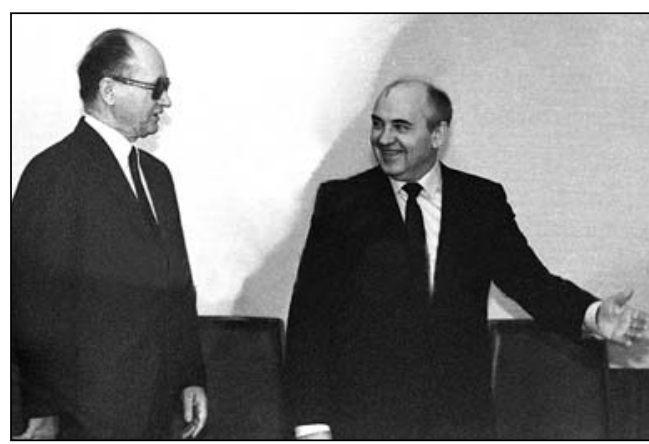

Generál Wojciech Jaruzelski byl patrně jediný z vůdců „bratrských zemí", kterého si Michail Gorbačov opravdu vážil jako politického partnera. Setkání v Kremlu koncem dubna 1989 se odehrálo $v$ době, $k d y$ Polsko směrovalo $k$ částečně svobodným volbám, $v$ nichž komunisté utrpèli zdrcující poráǎku, nicméně Jaruzelského na základě dohod se Solidaritou vynesly do prezidentského úř́adu uspěchaný a improvizovaný.

Sovětská politika vůči východní Evropě trpěla tím, že jí nebyla věnována soustavná pozornost. Členové politbyra od Gorbačova pravidelně slýchali prohlášení o strategické důležitosti východní Evropy a o nutnosti důkladně přehodnotit vztahy s tímto regionem. Informace, jež o východní Evropě dostávali, však pocházely většinou ze zpráv o návštěvách různých činitelů v této oblasti, které se omezovaly na obecné komentáře o vývoji v jednotlivých zemích. $V$ politbyru i na nižších úrovních v podstatě chyběla systematická a ucelená analýza toho, jakým způsobem by Moskva měla změnit svou politiku. ${ }^{15}$

14 Viz např. MUSATOV, Valerij Leonidovič: Metamorfozy politiki Gorbačeva v otnošeniji stran socialističeskogo sotrudničestva. In: Novaja i novejšaja istorija, č. 2 (2009), s. 3-18. I Georgij Šachnazarov ve svých memoárech Cena svobody uznává některé nedostatky této politiky (s. 121, viz pozn. 8). Jako prríklad soudobé tvrdé vnitřní kritiky lze uvést memorandum mezinárodního oddělení ÚV KSSS „Towards a New Conception of Relations between the USSR and the States of Central and Eastern Europe“ z počátku ledna 1990, které v záhlaví nese jména Šachnazarova, Rybakova a Ozereljeva a které v překladu historika Vladislava Zuboka je uloženo v Národním bezpečnostním archivu ve Washingtonu (viz http://www.wilsoncenter.org/ cwihp/documentreaders/eotcw/900109.pdf).

15 Gorbačovova výše zmíněná zpráva z 26.6.1986 (viz pozn. 2) volala po důkladném přehodnocení, zatímco na schůzi politbyra o necelé dva roky později sovětský generální tajemník zdůrazňoval potřebu „zásadni“" „vědecké analýzy“ (Archiv Gorbačev-Fonda (Moskva), fond 2, opis (inventáŕ) 2, poznámky Gorbačovova poradce Anatolije Čerňajeva z jednání politbyra ÚV KSSS 10.3.1988). 
Neustále se objevovaly stížnosti na strnulost a nepružnost společných institucí východního bloku, zvláště pak Rady vzájemné hospodářské pomoci, která sklízela větší kritiku než Varšavská smlouva. Kreml měl obecnou představu o dalším rozvoji těchto institucí - chtěl vytvořit prostředí, které by dávalo jednotlivým členským zemím pocit, že s nimi Moskva počítá, což by naopak přimělo tyto země k tomu, aby vyvinuly větší vlastní úsilí. Jak už jsem zmínil, byl stanoven i vizionářský cíl - přeměnit celý blok ve společenství spojeneckých zemí, založené spíše na dobrovolné účasti všech než na vnucených zájmech Moskvy. Nebylo však jasné, jak chce Kreml tohoto cíle dosáhnout. Množila se dobře myšlená prohlášení o častějších konzultacích a o vzájemné otevřenosti uvnitř bloku. Ve skutečnosti však staré zvyklosti přetrvávaly a uvolněnější forma vzájemné komunikace posloužila pouze $\mathrm{k}$ tomu, aby vyvstaly rozdíly mezi národními zájmy ve Varšavské smlouvě, a zejména v RVHP, což představovalo trvalou překážku v cestě nastoupených reforem. ${ }^{16}$

Neuspořádanost politických úvah Moskvy o východní Evropě byla částečně důsledkem nedostatečné pozornosti, kterou věnovala koncipování strategie vůči této oblasti během prvních tří let perestrojky. Kapacita pro tvorbu východoevropské politiky se zdála omezená, jak kvůli politické situaci, tak kvůli celkovému přetížení. Mnoho odborníků na východní Evropu, zvláště na Německou demokratickou republiku, bylo poněkud odsunuto do pozadí kvůli jejich poměrně silně konzervativnímu smýšlení. Lidé v Gorbačovově týmu, kteří byli za politiku vůči této oblasti odpovědní, bud' postrádali představivost, což byl př́ípad Vadima Medveděva, vedoucího oddělení pro spojení s komunistickými a dělnickými stranami socialistických zemí Ústředního výboru KSSS, nebo byli př́liš zatíženi jinými úkoly, jako například poradce pro socialistické země Georgij Šachnazarov.

Zcela zásadní bylo, že klíčoví protagonisté v Kremlu se nezdáli být ochotni věnovat východoevropské politice dostatečnou pozornost. ${ }^{17}$ Gorbačov východoevropské země navštívil a setkal se s místními vedoucími představiteli pouze z pocitu povin-

16 Např́klad na jednání Politického poradního výboru Varšavské smlouvy ve Varšavě 15.7.1988 Gorbačov zdůrazňoval nutnost změny. O rok později v Bukurešti poznamenal, že ve skutečnosti nebylo v tomto směru nic vykonáno. (Viz MASTNY, V. - BYRNE, M. (ed.): A Cardboard Castle?, s. 612-614 a 645 - viz pozn. 9; přehled dění v rámci Varšavské smlouvy v těchto letech viz tamtéž, s. 57-65.)

17 Valerij Musatov, tradičně smýšlející úředník, který působil na odboru socialistických zemí ÚV KSSS a byl v letech 1989-1991 zástupcem vedoucího mezinárodního oddělení, upozorňoval na to, že Alexandr Jakovlev a další důležití členové užšího týmu generálního tajemníka zanedbávají tuto oblast (podle autorova záznamu rozhovoru s Musatovem v Moskvě 2.12.1997). Podle Anatolije Čerňajeva nebyla východoevropským otázkám zpravidla věnována při vytváření sovětské politiky větší pozornost (viz záznam rozhovoru autora s Čerňajevem v Moskvě 4.12.1997). Vadim Medveděv naopak trval na tom, že oblast byla poměrně vysoce prioritní a že Čerňajev a ostatní lidé z ústředí, kteří se nevěnovali př́mo východní Evropě, často podceňovali její význam (podle záznamu rozhovoru autora s Medveděvem v Moskvě 10.12.1997). 
nosti. S výjimkou Wojciecha Jaruzelského, kterého uznával, připadaly Gorbačovovi jeho východoevropské protějšky nezajímavé, a dokonce ho rozčilovaly. Setkání se západoevropskými politiky, jako např́klad s Margaret Thatcherovou, Françoisem Mitterrandem, Helmutem Kohlem a Felipem Gonzalesem, byla pro něj živější, náročnější, a proto interesantnější. Jednání s východoevropskými předáky ho většinou nepřitahovalo, a stejně tak i změnu politiky vǔči této oblasti považoval za méně významnou prioritu. Bylo jasné, že vztahy Sovětského svazu s východní Evropou by potřebovaly nový impulz, ve srovnání se snahou o radikální zlepšení vztahů se Západem se však jednalo o druhořadou záležitost.

Problémy v této oblasti se nejevily tak naléhavé a stejně tak potenciální výnosy plynoucí ze změny sovětské strategie se nezdály být tak velké. Důvěrná znalost silných a slabých stránek politiky ve východní Evropě otupila obavy Kremlu a způsobila, že se $\mathrm{k}$ problémům $\mathrm{v}$ regionu stavěl poněkud přehlíživě. Až velice pozdě, v listopadu 1988, Gorbačovovu pozornost připoutala vážnost tamní krize a naléhavá potřeba přehodnotit strategii. Georgij Šachnazarov hlásil, že se ve východní Evropě objevují znaky systémové krize, a naléhal na to, aby byly učiněny kroky k zásadnímu přehodnocení východoevropské politiky, o nichž se dlouho uvažovalo, ale které nebyly nikdy podniknuty. ${ }^{18}$ Nutnost přijít se strategickým plánem vyvstala před Gorbačovem zcela jasně na počátku roku 1989, kdy se západní činitelé začali Moskvy dotazovat, jak hodlá reagovat na možné budoucí snahy socialistických států připojit se $\mathrm{k}$ Evropskému hospodářskému společenství. ${ }^{19}$ Gorbačovův poradce pro zahraniční politiku Alexandr Jakovlev zadal vypracování čtyř analýz dalšího vývoje ve východní Evropě (tř́i ze stranických a státních institucí a jedné z politického výzkumného ústavu). Tyto zprávy nastínily různě pesimistické scénáře, přičemž se přikláněly spíše k negativnějšímu pohledu. Radikální a ucelená politická doporučení se objevila pouze ve zprávě výzkumného centra, zatímco doporučení od stranických orgánů a vládních úřadů byla neurčitá a nahodilá. ${ }^{20}$ Zprávy byly projednány,

18 Šachnazarovova zpráva na schůzi politbyra ÚV KSSS 6.10.1988 zdůrazňovala naléhavou nutnost vytvořit „koncepci“ $\mathrm{k}$ řešení situace, v níž Šachnazarov spatřoval bezprostřední nebezpečí vypuknutí krize (viz ŠACHNAZAROV, G.: Cena svobody, s. 367 n. - viz pozn. 8). Text zprávy vyšel v překladu v CWIHP Bulletin, č. 12-13 (2001), s. 15 n. Jediná diskuse týkající se východní Evropy, kterou Anatolij Čerňajev zaznamenal na jednání politbyra 6.10.1988, se týkala obchodních záležitostí (viz GORBAČOV, M. S.: Sobranije sočiněnij, sv. 12, s. 165 n. - viz pozn. 5).

19 Čerňajevovy záznamy z rozpravy politbyra ÚV KSSS 21.1.1989 jsou přeloženy v CWIHP Bulletin, č. 12-13 (2001), s. 16 n. Tento text tvoří součást rozsáhlejších poznámek z uvedeného jednání politbyra, které se však zřejmě konalo spíše 24. než 21. ledna (viz V Politbjuro TsK KPSS..., s. 432-438 - viz pozn. 2).

20 Anglické překlady zpráv z Bogomolovova ústavu, mezinárodního oddělení ÚV KSSS a sovětského ministerstva zahraničí viz CWIHP Bulletin, č. 12-13 (2001), s. 52-71. Dokument, který vypracovala KGB, zůstává nadále nedostupný. 
ale nezdá se, že by vedly k systematičtějšímu přehodnocení politiky, a už vůbec ne $\mathrm{k}$ vypracování ucelené strategie odrážející nové priority. Kreml pokračoval v provádění politiky prostřednictvím sledu improvizovaných reakcí na události, které v létě 1989 přerostly ve stupňující se sérii dramatických otřesů v celé oblasti.

Kremlu, a zvláště Gorbačovovi osobně se samotná zmínka o aktivnější politice viơci východní Evropě mohla zdát nadbytečná a nepatřičná. $Z$ jeho pohledu byla představa aktivní snahy o utváření vztahů $\mathrm{v}$ regionu spojena s podobnými pokusy v minulosti, které zpravidla skončily draze zaplaceným fiaskem. Nechut a nezájem o aktivní př́stup $\mathrm{k}$ východní Evropě vyústily v záměrně odtažitý postoj. Gorbačov věřil, či alespoň přesvědčil sám sebe, že jediná osvícená politika vůči regionu spočívá v odmítnutí vedoucí role, kterou se v minulosti Moskva vždy snažila zastávat. Narozdíl od některých členů svého týmu nepovažoval tento jednostranný posun od dominance $\mathrm{k}$ jemně prováděnému poradenství za nerealistický či destabilizující. Podcenil přitom sílu navyklé závislosti ve východní Evropě, která se utvořila během čtyř desetiletí imperiální sovětské vlády, a přecenil schopnost východoevropských představitelů důvěřovat jeho prohlášením o tom, že Moskva nyní skutečně chce, aby jejich země usilovaly o nezávislý rozvoj, a jednat $\mathrm{v}$ souladu s těmito prohlášeními. ${ }^{21}$ Sovětský svaz již neměl nadále působit $\mathrm{v}$ roli velitele ani ručitele, východoevropští vedoucí představitelé se o sebe měli postarat sami.

Gorbačov toto poselství sděloval na neveřejných jednáních, počínaje setkáním vedoucích představitelů socialistických zemí na pohřbu generálního tajemníka sovětských komunistů Konstantina Ustinoviče Černěnka v březnu 1985. Na veřejnosti hovořil nový generální tajemník od roku 1987 vytrvale o neintervenci a svobodné volbě. I když si uvědomoval, že pro východoevropany bude těžké těmto prohlášením uvěřit, podcenil hloubku a odolnost jejich skepse. Východoevropští představitelé slyšeli již př́liš mnoho prohlášení z Moskvy o nutnosti přijmout zodpovědnost za vlastní země, a zvláště za osud svých ekonomik. Gorbačovovo vyjádření, že doba školky je u konce, se většině z nich zdálo být jednoduše potvrzením toho, že Moskva již není nadále ochotna podporovat a zachraňovat neschopné režimy. Východoevropští vůdci se zdráhali uvěřit tomu, že Moskva od základu změnila svůj př́stup a že nebude intervenovat za žádných okolností. V každém př́padě se jednání založené na podobných prohlášeních jevilo jako dvojnásob riskantní. I v př́ípadě, že Gorbačov myslel své sliby vážně, nemusel být schopen je dodržet a mohl být naopak snadno nahrazen konzervativnějším nástupcem.

21 V rozhovoru s autorem v Moskvě 28.4.1999 Gorbačov přiznal, že měl přehnaná očekávání ohledně príjetí svého poselství. Ve svých pamětech zdůrazňuje zakořeněnost starých návyků mezi vedoucími činiteli ve východní Evropě (viz GORBAČOV, M. S.: Žizň $i$ reformy, sv. 2, s. 312 n.; v českém znění: PREČAN, V. (ed.): Svědectví o rozpadu „socialistického společenství", s. 515 - viz pozn. 2). 
Teprve v létě a na podzim 1989, kdy východoevropští představitelé viděli, že Moskva je skutečně připravena akceptovat radikální politické změny, uvěřili, že Gorbačov myslel svá slova o neintervenci vážně. ${ }^{22}$ I poté však nadále považovali Moskvu za významný faktor ovlivňujíć jejich vnitropolitické kalkulace a za rozhodujícího činitele v úvahách zahraničněpolitických. Konzervativnější politici zůstávali zdrženliví, pokud šlo o nepř́mé pobídky Moskvy ke změnám, reformátoři se snažili získat v Moskvě podporu. Bez ohledu na snahu Gorbačova nezaplétat se do vnitřních záležitostí východoevropských států zůstával Kreml klíčovým faktorem regionální politiky. Tuto skutečnost posilovalo každodenní chování Moskvy. Sovětští návštěvníci včetně Gorbačova, kteří do oblasti přijížděli, aktivně propagovali př́nos, který by znamenaly změny po vzoru perestrojky. Sám generální tajemník se občas, byṫ neochotně, nechal přimět $\mathrm{k}$ podpoře východoevropských reformátorů, a tak posiloval jejich postavení vůči konzervativcům, odmítajícím změny.

Zatímco Kreml od jara 1989 zjištoval, že se pohybuje ve stále rozbouřenějších politických vodách, Gorbačov se ještě pevněji držel dvou hlavních myšlenkových východisek, která představovala $\mathrm{v}$ praxi klíčové zásady pro utváření sovětských reakcí na vývoj v oblasti. Prvním východiskem byla víra ve schopnost místních komunistických stran projít obrodným procesem a postavit se do čela změn; podobné úvahy posilovaly jeho optimismus ohledně schopnosti socialistických reformátorů přečkat zuř́íí bouři. Druhé východisko, které ŕídilo reakce Moskvy, byl Gorbačovův odpor vůči ozbrojené intervenci jako prostředku řešení konfliktů. Jeho nechut k užití síly odrážela a zároveň posilovala zdrženlivost v reakcích na vývoj v oblasti. Tuto zdrženlivost během roku 1989 dále utvrzovaly obavy z nestability v regionu, která mohla ohrozit sbližování Sovětského svazu se Západem, a dokonce i samotný proces perestrojky.

\section{Klíčové trendy $v$ sovětské politice}

Optimismus a opatrnost se $\mathrm{v}$ různých kombinacích projevují $\mathrm{v}$ šesti hlavních trendech, které lze vypozorovat v angažmá Moskvy v oblasti východní Evropy a které jsou nastíněny v následujících kapitolách. Tyto politické trendy společně ukazují Moskvu jako nerozhodného a zdrženlivého hráče, který chtěl aktivně pomoci východoevropským zemím, aby pomohly samy sobě reformou socialismu, který se ale zároveň nechtěl vměšovat do jejich domácího dění. Kreml se snažil nastartovat reformy pod vedením komunistů, ze všech sil se však vyhýbal krokům - at již ze strany Moskvy či lokálních aktérů - které by mohly vyvolat konflikt a tak zvýšit nestabilitu.

22 Ještě ani na podzim 1989 nemělo polské vedení zdaleka jasno v tom, jaká je politika Moskvy (viz RAKOWSKI, Mieczysław F: Dzienniki politicyzne 1987-1990. Varszawa, Iskry 2005, s. 534). 


\section{Propagace perestrojky}

Postoj Moskvy vůči perestrojce v rámci východního bloku vytvořil dva zdroje napětí, které ovlivňovaly sovětskou politiku vůči východní Evropě v celé její šíri. První vzešel z nesouladu mezi Gorbačovovým závazkem neintervenovat a jeho touhou propagovat perestrojku. Druhý zdroj napětí pocházel z úsilí o perestrojkové reformy, které měly sice přinést modernizaci, aniž by však vyvolaly rozkladnou nestabilitu.

Způsob, jakým Moskva perestrojku prosazovala, ukazoval, že Gorbačovovo odmítání starých sovětských postupů neznamenalo v praxi úplný konec uplatňování jejího vlivu v regionu. Přinesl spíše posun od přímého vměšování do východoevropských záležitostí směrem $\mathrm{k}$ působení na prostř̌edí, $\mathrm{v}$ němž místní představitelé přijímali svá vlastní rozhodnutí. Nový př́stup v praxi znamenal, že se Moskva pokusí vyhnout násilnému vnucování svých preferencí a omezí se na „pasivni““ ovlivňování prostř̌ednictvím vlastního prríkladu. ${ }^{23}$ Lze říci, že se Kreml ve většině př́ípadů skutečně řídil tím, co hlásal. Moskva byla spokojena s rolí diváka a s umožněním šǐření informací o perestrojce, které měly vytvořit vhodné klima pro reformy.

V tomto obecném umenšení vlastní role bylo však možno nalézt i prvky aktivního př́stupu. Když se konzervativně smýšlející místní vedoucí představitelé pokoušeli omezit šírení informací o perestrojce, začala se Moskva chovat neodbytněji. Kreml káral východní Němce, kteří se podobných přečinů dopouštěli nejčastěji, za jejich snahu třídit a cenzurovat zprávy o postupu sovětských reforem. Moskva rovněž vystupňovala vlastní úsilí o propagaci perestrojky. ${ }^{24}$ I tam, kde místní představitelé vyjadřovali perestrojce svou podporu, at se již jednalo o skutečné ztotožnění s ní či o formální proklamace, Kreml stále podnikal aktivní kroky k šíření informací. Při všech svých návštěvách v oblasti Gorbačov vychvaloval reformy, které podnikal doma. Snažil se uchlácholit místní vưdce a vyhnout se přímému nařizování, ale podstata jeho veřejného poselství - nutnost nechat se inspirovat duchem perestrojky - neunikla davům lidí, kteří si ho přišli poslechnout. Na uzavřených setkáních s vůdci „bratrských“ stran se sovětský generální tajemník rovněž pečlivě vyhýbal starému modelu direktivního vystupování svých předchůdců. Zdůrazňoval naopak, že je nutné, aby místní představitelé činili svá vlastní rozhodnutí. Časté paralely, které hledal mezi

23 Jak řekl Gorbačov na jednání politbyra 29.1.1987, měli by sovětští představitelé uplatňovat svůj vliv pouze prostřednictvím toho, co sami konali v SSSR (viz GORBAČOV, M. S.: Sobranije sočiněnij, sv. 5, s. 465 - viz pozn. 5; TÝŽ: Žizň i reformy, sv. 2, s. 338 n. - viz pozn. 2).

24 Svědčí o tom hodnocení a doporučení $v$ Jakovlevově podnětné zprávě ze 17.8.1987 o návštěvě NDR v létě toho roku: Zapiska A. N. Jakovleva v TsK KPSS ob otnošeniji rukovodstva SEPG $\mathrm{k}$ perestrojke $\mathrm{s}$ priloženijem perečenija voprosov, najboleje často zadajemych $\mathrm{v}$ německich auditorijach pri vystuplenijach po itogom janvarskogo (1987g) i ijuňskogo (1987g) plenumov TsK KPSS. In: JAKOVLEV, Alexandr N. (ed.): Perestrojka: 1985-1991. Něizdannoje, maloizvestnoje, zabytoje. Moskva, Meždunarodnyj fond „Děmokratija“ 2008, s. 135-151, obzvláště s. $141-147$. 
problémy, jimž čelili, a potížemi, na které narážela perestrojka, se však v praxi rovnaly doporučením prostřednictvím uplatňování analogie. ${ }^{25}$ Takto jeho vyjádření rovněž často interpretovali východoevropští představitelé a veřejnost. Kreml často kráčel po hranici oddělující pouhý výklad od doporučení, a někdy ji i překračoval. ${ }^{26}$

Posuny v př́ístupu sovětského vůdce odrážely prvotní napětí mezi dvojí prioritou - změnou a stabilitou - o němž již byla řeč. Kreml chtěl, aby se perestrojka stala „zásadním impulzem“ pro změnu a modernizaci, zároveň si však přál, aby při této změně byla zachována stabilita. Jak Gorbačov prohlásil na setkání vedoucích představitelů zemí Varšavské smlouvy v červenci 1988, usiloval o „stabilitu spojenou s procesem obnovy“ “. ${ }^{27}$ Dosažení obou těchto cílů se ale ukazovalo obtížné. Napětí, které mezi nimi panovalo, ztěžovalo propagaci perestrojky. Př́liš̌ silné výzvy ze strany Moskvy ve prospěch změny typu perestrojky byly spojeny s rizikem, že dojde k oslabení jednoty místních komunistických stran a jejich vedení. Př́liš opatrný př́stup naopak usnadňoval konzervativním předákům, aby odmítali požadavky na změny, a nesl s sebou riziko oslabení schopnosti komunistické strany postavit se do čela reforem. Dosažení rovnováhy bylo obtížné. Gorbačov obvykle vyhlašoval nutnost změn, zpravidla ale chyboval v tom, že byl př́liš opatrný a bránil se prosazování skutečně radikálních reforem.

Problémy s nalezením rovnováhy při propagaci perestrojky se lišily podle zemí. Tam, kde byli místní vedoucí představitelé v zásadě srozuměni s podporou agendy perestrojky, jako např́klad v Mad’arsku či Polsku, se tyto problémy zdály nejmenší. Za podobných okolností nadšení veřejnosti, které provázelo Gorbačovova vystoupení, sovětského vi̊dce spíše rozradostňovalo, než znervózňovalo. Gorbačov byl například nadšen ohlasy na svou cestu do Polska v červenci 1988, které si vykládal jako potvrzení potenciálu perestrojky coby impulzu pro reformy pod vedením komunistů. ${ }^{28} \mathrm{Na}$ druhé straně politického spektra byla naopak Německá demokratická republika, kde byli někteří členové vedení vưči perestrojce otevřeně kritičtí a vnímali její propagaci jako hrozbu. Tím vznikala pro Kreml velice obtížná situace.

25 Např́klad při jednání s vedením Komunistické strany Československa v Praze v dubnu 1987 (viz Iz besedy s členami Prezidijuma i sekretarjami TsK KPČ, 10 aprelja 1987 goda. In: GORBAČOV, M. S.: Sobranije sočiněnij, sv. 6. Moskva, Ves Mir 2008, s. 260-265).

26 Alexandr Jakovlev údajně perestrojku prosazoval dosti intenzivně při své návštěvě v Praze v listopadu 1988 (viz Národní archiv (Praha), bývalý Archiv Komunistické strany Československa, fond Předsednictvo ÚV KSČ, č.j. 6367/24, Zpráva o průběhu a výsledcích jednání pracovní návštěvy člena politického byra a tajemníka ÚV KSSS Alexandra N. Jakovleva v ČSSR, Př́loha III k Usnesení předsednictva ÚV KSČ dne 18.11.1988).

27 Viz Vystuplenije na vstreče geněralnych, pervych sekretarjej TsK - glav dělegacij, učastvovavšich v PKK v Varšave 12 ijulja 1988 goda. In: GORBAČOV, M. S.: Sobranije sočiněnij, sv. 11, s. 350 (viz pozn. 3).

28 Viz GORBAČOV, M. S.: Žizň i reformy, sv. 2, s. 340 n. (viz pozn. 2); Gorbačovi̊v komentář k návštěvě Polska viz Iz vystuplenij na zasedaniji Politbjuro TsK KPSS, 21 ijulja 1988 goda. 


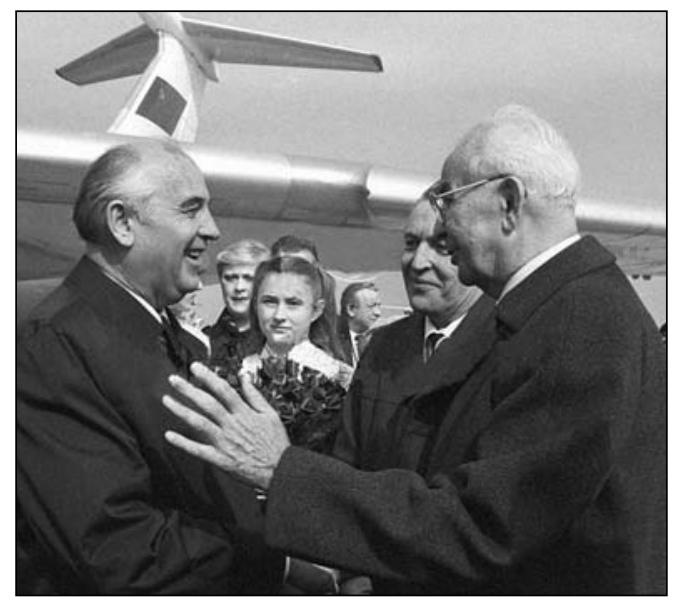

Prezident a generální tajemník Ústředního výboru KSČ Gustáv Husák (1913-1991) vítá 9. dubna 1987 na Ruzyňském letišti Michaila Gorbačova. Československo bylo $v$ Kremlu vnímáno jako neproblematická země a Gorbačov se vǐči němu striktně držel své koncepce nezasahování do vnitropolitických poměrů, což se ke zklamání mnoha obyvatel projevilo i při oficiální návštěvě Prahy
Snaha Moskvy předat poselství o perestrojce východoněmeckým občanům ještě více znervózňovala vedení Jednotné socialistické strany Německa a posilovala jeho vzdorovitost. Snaha vyhnout se oslabení jednoty východoněmeckých komunistů a jejich kontroly nad událostmi vedla Gorbačova ke zdrženlivosti při prosazování perestrojky způsobem, který by mohl podpořit destabilizující iniciativy vůči linii Ericha Honeckera. ${ }^{29}$

Československo, které se nacházelo uprostřed východoevropského politického spektra, vyžadovalo velice jemně vyváženou propagační politiku, nebot' zde perestrojka vyvolávala silné reminiscence pražského jara 1968. Drtivá většina společnosti doufala, že perestrojka s sebou přinese revizi sovětské intervence ze srpna 1968 a dlouho odkládanou

oblevu politických poměrů, zamrzlých v procesu „normalizace“, který následoval po invazi vojsk Varšavské smlouvy. Československé vedení bylo rozdělené - většina se perestrojky obávala, ale předstírala souhlasný postoj k reformám Moskvy ze zvyku podřizovat se jí, a několik málo členů vedení bylo připraveno udělat malé krůčky směrem k perestrojce. Kombinace nadšené veřejnosti a rozdělené stranické elity představovala pro Gorbačova dilema. Když zemi v dubnu 1987 navštívil, byl ohromen davy, které ho vítaly téměř jako osvoboditele a které očekávaly, že řekne něco kladného o pražském jaru a pomůže tak nastartovat nový reformní proces.

In: GORBAČOV, M. S.: Sobranije sočiněnij, sv. 11, s. 405; viz rovněž MEDVEDĚV, Vadim A.: Raspad: Kak on nazreval v „mirovoj sistěme socializma“. Moskva, Meždunarodnyje otnošenija 1994, s. 87 n.

29 Při jednání s Honeckerem Gorbačov nadále prosazoval perestrojku jen velice opatrně (viz Iz besedy s Geněralnym sekretarijem TsK SEPG E. Gonekkerom 28 sentjabrja 1988 goda. In: GORBAČOV, M. S.: Sobranije sočiněnij, sv. 12, s. 108-115 (viz pozn. 5); viz rovněž MEDVEDĚV, V. A.: Raspad, s. 170). 
Sovětský vůdce však události roku 1968 nijak nepřehodnotil a naopak chválil úspěchy dosažené v uplynulém období, tedy za „normalizace“. ${ }^{30}$

Stanovisko, které Gorbačov zaujal k roku 1968, v sobě obsahovalo některé prvky optimismu a značnou dávkou opatrnosti. Poněkud optimisticky doufal, že kladné zmínky o aktuálních úspěších dodají československé veřejnosti i komunistické elitě sebedůvěru k tomu, aby se vydaly cestou perestrojky. ${ }^{31}$ Domníval se, že svůj osvícenější postoj demonstroval už tím, že odmítl přistoupit na požadavek vedení KSČ, aby schválil srpnovou invazi. To však byl pro davy naplněné očekáváním příliš nenápadný signál. Gorbačovův konzervativní přístup k československým reformám roku 1968 odrážel jeho vlastní rozpolcený pohled na radikálnější prvky vývoje z léta onoho roku. ${ }^{32}$ Jestliže odmítl vynést rok 1968 jako trumfovou kartu, bylo to ale v zásadě dáno především opatrností. Gorbačov se obával, že kladné zmínky o pražském jaru by narušily křehkou jednotu stranického vedení a jeho schopnost držet pod kontrolou tlak na změny, který by revizionistickými poznámkami o roce 1968 získal další impulz. Kromě těchto praktických úvah pocitoval navíc Gorbačov i určitou zodpovědnost za ostatní komunistické vůdce. V Československu stejně jako jinde chtěl propagovat perestrojku způsobem, který považoval za „zodpovědný“, a vyhnout se vnucování „spletence myšlenek“, které mohly vést k destabilizaci situace a - jak varoval členy politbyra - ke „zničení všeho“..33 Sovětský vůdce doufal takřka až do poslední chvíle, že šíření perestrojky s pomocí její opatrné propagace vyústí ve spořádanou reformu řízenou komunisty.

\section{Neochota prosazovat výměnu konzervativních vůdců}

Výše zmíněné obavy rovněž pomáhají vysvětlit, proč se Kreml zdráhal přispět k odstranění konzervativních východoevropských předáků. V tomto směru hrály svou

30 Viz Gorbačovovy poznámky o návštěvě Československa na jednání politbyra ÚV KSSS 16.4.1987 (Iz vystuplenij na zasedaniji Politbjuro TsK KPSS (16. aprelja 1987 goda). In: GORBAČOV, M. S.: Sobranije sočiněnij, sv. 6, s. 345-347; k návštěvě dále tamtéž, s. 247-291 - viz pozn. 25). Pozdější úvahy na toto téma viz TÝŽ: Žizň i reformy, sv. 2, s. 352-354 (v českém znění viz PREČAN, V. (ed.): Svědectví o rozpadu „socialistického společenstvi“", s. 522-524 - viz pozn. 2).

31 Vypovídá o tom velice živá výměna názorů v publikaci: GORBACHEV, M. S. - MLYNAR, Z.: Conversations with Gorbachev on Perestroika, the Prague Spring, and the Crossroads of Socialism, s. 86-88 (v českém vydání: TíŽ: Reformátoři nebývají štastni, s. 70-73).

32 Ve své zprávě pro sovětské politbyro z 16.4.1987, podobně jako během rozhovorů s československým vedením, zaujal Gorbačov pozitivní přístup k prvotním reformním idejím pražského jara, jak byly prezentovány v lednu 1968, když zde nacházel podobnosti s perestrojkou. Negativně se naopak postavil $\mathrm{k}$ letním událostem osmašedesátého roku, které podle něj vedly k podvracení socialismu. (Viz GORBAČOV, M. S.: Sobranije sočiněnij, sv. 6, s. 347 - viz pozn. 25.) Gorbačovův komplikovaný vztah k roku 1968 je popsán rovněž v pamětech Georgije Šachnazarova Cena svobody, s. 105 (viz pozn. 8).

33 Iz vystuplenij na zasedaniji Politbjuro TsK KPSS 19 nojabrja 1987 goda. In: GORBAČOV, M. S.: Sobranije sočiněnij, sv. 9. Moskva, Ves Mir 2009, s. 29. 
roli jak principiální, tak pragmatické úvahy. Gorbačov osobně byl rozhodnut dodržovat princip neintervenovat do vnitřních záležitostí regionu. Pro tento postoj měl rovněž relevantní praktické důvody. Jeho tým z minulých sovětských zkušeností vyvodil mimo jiné poučení, že východoevropští politikové by měli mít možnost řešit své vzájemné rozpory a problémy sami. Vměšování ze strany Moskvy se obvykle ukazovalo jako kontraproduktivní, účinnější bylo zaujmout odměřený a odtažitý př́stup. ${ }^{34}$ Gorbačov si obzvlášt zřetelně uvědomoval, že sovětské vměšování do politiky vedení východoevropských komunistických stran, beztak již vystavených tlaku požadavků po změně, by je mohla dále rozkolísat.

I přes tyto obavy byl však Kreml občas ochoten nabídnout pomocnou ruku místním funkcionářům, kteří chtěli odstranit konzervativní vůdce. Nejlepším příkladem, kdy se Moskva rozhodla odchýlit od své nově přijaté omezené role, byla nejspíše intervence při odstranění Jánose Kádára v květnu 1988. Tento sovětský zásah lze rozdělit do dvou fází, jež tvoří vlastní angažmá a dodatečné schválení. Předseda KGB Vladimir Krjučkov, který znal Kádára již od roku 1956, kdy působil na sovětském velvyslanectví $\mathrm{v}$ Budapešti, se zapojil do posledních fází procesu odstranění vysloužilého funkcionáře. V dubnu 1988 navštívil Budapešt a údajně pomohl překonat odpor starého muže, který se nechtěl vzdát funkce generálního tajemníka Mad’arské socialistické dělnické strany (MSDS). Později v dubnu přivezl předseda sovětské vlády Nikolaj Ryžkov do Budapešti souhlas Kremlu se změnou vedení. Nakonec, vpředvečer zasedání, na němž $\mathrm{k}$ této změně došlo, zavolal Gorbačov Kádárovi a snažil se mu usnadnit odchod tím, že pochválil toto jeho moudré rozhodnutí. ${ }^{35}$

Tento poměrně diskrétní, přesto však významný sovětský zásah byl založen na dvou premisách, jež souvisely s důrazem na zachování stability v Mad’arsku. První premisou byl pocit Kremlu, že starý vůdce, ke kterému Gorbačov pocitoval spíše respekt než sympatie, se stává skutečnou překážkou reforem, a tudíž nebezpečnou politickou zátěží. Již více než rok před jeho odstraněním si Moskva začala uvědomovat, že Kádár ztrácí kontakt s vývojem v Mad’arsku. Na jaře 1988 dospěla k závěru, že Kádár se stal zásadní překážkou omezující možnost vnitřní obrody Mad’arské socialistické dělnické strany a její schopnost řešit stupňující se hospodářské a politické problémy země. ${ }^{36}$ Stejně důležité bylo, že o této skutečnosti panoval dostatečně široký konsenzus v mad’arském politickém vedení. Různí jeho členové

34 Iz vystuplenij na zasedaniji Politbjuro 29 janvarja 1987 goda. In: TÝŽ: Sobranije sočiněnij, sv. 5, s. 465 (viz pozn. 5).

35 Viz MEDVEDĚV, V. A.: Raspad, s. 128-131 (viz pozn. 28). Potvrdil to Valerij Musatov v rozhovoru s autorem v Moskvě 2.12.1997. Shrnutí rozhovoru Gorbačova s Kádárem 19.5.1988 obsahují memoáry sovětského státníka (GORBAČOV, M. S.: Žizň i reformy, sv. 2, s. 328-333 - viz pozn. 2).

36 Viz MEDVEDĚV, V. A.: Raspad, s. 126 n. 
se již delší dobu snažili získat podporu Moskvy k tomu, aby odstranili starého muže $\mathrm{z}$ jeho funkce. Kreml se ale do celého procesu vložil teprve $\mathrm{v}$ okamžiku, kdy byl spokojen se širíí konsenzu, zajištujícího jednotu a spořádané předání moci. I když si ve své opatrnosti uvědomoval možná rizika, dospěl $\mathrm{k}$ závěru, že jeho nečinnost by byla ještě riskantnější a umožnila by Kádárovi nadále blokovat reformy potřebné k odvrácení krize.

Okolnosti, které přiměly Kreml zasáhnout při odstranění vysloužilého funkcionáře v Madarsku, jinde ve východní Evropě nenastaly. Československý vůdce Gustáv Husák byl ještě zdrženlivější než Kádár, pokud šlo o změnu kurzu, ale v tomto př́padě měl Kreml menší obavy $\mathrm{z}$ toho, že nečinnost povede $\mathrm{k}$ vážné krizi. ${ }^{37}$ Soudruzi ve vedení Komunistické strany Československa nakonec Husáka dokázali přesvědčit, aby se vzdal funkce generálního tajemníka, aniž by přitom potřebovali aktivní podporu Moskvy. Sovětské politbyro bylo na oplátku svolné $\mathrm{k}$ „přátelským rozhovorům" o všech problémech, rádo ale přenechalo rozhodování Praze. ${ }^{38}$

Ze všech vzpurných vysloužilých politiků byl nejvíce nepoddajný Erich Honecker a skutečnost, že byl odstraněn př́liš pozdě, měla pro Moskvu zdaleka nejzávažnější následky. Jak již bylo zmíněno, Honecker se postavil na odpor perestrojce a ze všech sil se snažil podnítit kritiku Gorbačovových názorů v NDR, ve východním bloku jako takovém, a dokonce i v samotném Sovětském svazu. Jeho chování jen potvrzovalo názor, který si na něj Kreml vytvořil - viděl ho jako nepř́jemného, arogantního člověka, přesvědčeného o vlastní neomylnosti. Jak sarkasticky poznamenal na jeho adresu Gorbačov, Honecker byl papežštější než papež. ${ }^{39}$ Přesto nic nenasvědčuje tomu, že by se Kreml stavěl vstřícně vůči př́ležitostem, aby pomohl starého politika odstranit. Několik pokusných signálů, které v této věci Východní Německo do Moskvy vyslalo, nevyvolalo v Kremlu žádnou reakci. Sovětští vůdci postrádali důkazy o tom, že by se vítr obracel proti Honeckerovi, a nadále předpokládali, že Jednotnou socialistickou stranu Německa (SED) zcela ovládají Honeckerovi spojenci. ${ }^{40}$ Kreml se domníval, že jakákoli podpora Honeckerových kriti-

37 Georgij Šachnazarov považoval Husáka za relativně spolehlivého centristu ve vedení strany (viz ŠACHNAZAROV, G.: Cena svobody, s. 107 n. - viz pozn. 8). Stejně se na něj díval i Gorbačov (viz GORBAČOV, M. S.: Žizň i reformy, sv. 2, s. 352 n.; v českém znění: PREČAN, V. (ed.): Svědectví o rozpadu „socialistického společenství“, s. 524 n. - viz pozn. 2).

38 Iz vystuplenij na zasedaniji Politbjuro TsK KPSS 19 nojabrja 1987 goda. In: GORBAČOV, M. S.: Sobranije sočiněnij, sv. 9, s. 29 (viz pozn. 33).

39 GORBAČOV, M. S.: Žizň i reformy, sv. 2, s. 405 n.; ŠACHNAZAROV, G.: Cena svobody, s. 25.

40 Viz MAXYMIČEV, Igor: Rekviem pro GDR. In: TÝŽ (ed.): Poslednij god GDR. Moskva, Meždunarodnyje otnošenija 1993, s. 22, 24 a 28; ADOMEIT, Hannes: Imperial Overstretch: Germany in Soviet Policy from Stalin to Gorbachev. Baden Baden, Nomos 1998, s. 378. Anatolij Čerňajev v rozhovoru s autorem v Moskvě 10.9.1998 sdělil, že tehdy přijel do Moskvy předseda východoněmecké vlády Willi Stoph a naznačoval možnost změny ve vedení země, Gorbačov ale odmítl jakkoli se v tomto směru angažovat. 


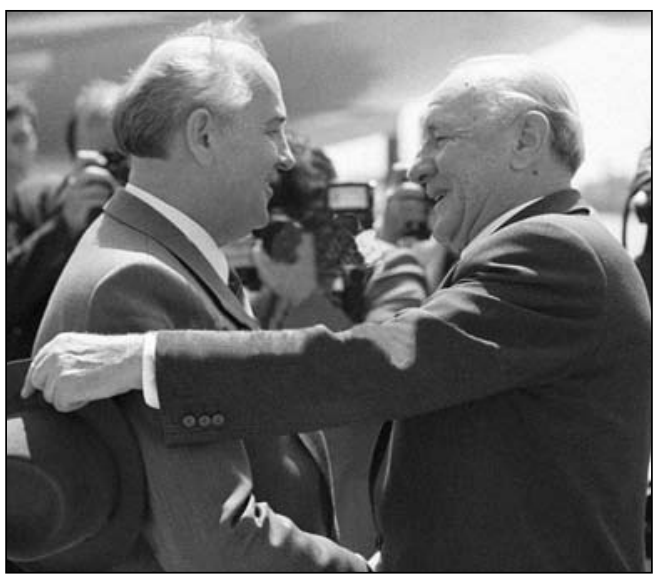

Srdečné úsmèvy nejvyšších představitelů Sovětského svazu a Madarska na letišti v Budapešti 1. června 1986 nedávají tušit, že o dva roky později bude János Kádár (1912-1989) v Moskvě hodnocen jako brzda potřebných reforem a že Gorbačovi̊v tým dopomůže $k$ jeho odchodu do politické penze ků by byla př́liš riskantní, jelikož by mohla přimět Honeckera a zastánce tvrdé linie, aby se zcela odvrátili od Moskvy. To by pak mohlo pro změnu vyvolat destabilizaci NDR a narušit Gorbačovovu politiku sbližování dvou rozdělených táborů v Evropě.

Během roku 1988 a ještě $v$ létě 1989 Gorbačov v kontaktu s Honeckerem zachovával zdvořilý př́stup a mírnou kritiku na jeho adresu kompenzoval rezolutním ujištováním o svém prátelství. Možnost, že tato umírněná taktika jen povzbudí Honeckera, aby setrval ve svém odporu, a tak uspíśi krizi, zjevně Kreml př́liš neznepokojovala. Moskva optimisticky považovala situaci v NDR za relativně stabilní. Gorbačovův tým zpravidla přehlížel kritičtější hodnocení přicházející z východního Ber-

lína a považoval je za projev pesimismu konzervativců, kteří chtějí zveličit tamní nestabilitu, aby tím dodali váhu svým protireformním argumentům. ${ }^{41}$ Teprve na podzim 1989 začal Kreml brát zprávy o hrozící krizi vážně. Ve stejné době obdržel první silnější signály o tom, že se ve vedení Jednotné socialistické strany Německa vítr obrací proti Honeckerovi. I tehdy však žádosti adresované Moskvě, aby zaujala jednoznačný postoj, narážely na její neochotu se angažovat. Gorbačov cítil odpor k tomu, aby byl zatažen do boje o vedení, zvláště pak ve východním Berlíně, kde se vývoj mohl obrátit $v$ neprospěch Moskvy a kde bylo v sázce př́liš mnoho. Až v záŕí ukázaly Gorbačovovi kritické zprávy z Východního Německa zcela jasně, že se země potácí na pokraji nebezpečné krize. Gorbačov později poznamenal, že si uvědomil, že NDR lze přirovnat $\mathrm{k}$ tlakovému hrnci s pevně přiklopeným víkem, přičemž hodinové ručičky ukazují za pět minut dvanáct. ${ }^{42}$

41 Viz Zapiska A. N. Jakovleva v TsK KPSS ob otnošeniji rukovodstva SEPG k perestrojke..., s. 140 (viz pozn. 24). Optimistický pohled na situaci v Německu lze najít i v memorandu mezinárodního oddělení ÚV KSSS z února 1989, publikovaném v CWIHP Bulletin, č. 12-13 (2001), s. 63 (viz pozn. 7).

42 GORBAČOV, M. S.: Žizň i reformy, sv. 2, s. 409-413 (viz pozn. 2). Anatolij Čerňajev v rozhovoru s autorem v Moskvě 10.9.1998 upozornil na neochotu sovětského vůdce jet do východního Berlína. 
Vědomí, že v NDR může dojít $\mathrm{k}$ výbuchu, pokud se nepodaří nějak zlomit odpor jejího vůdce $\mathrm{k}$ reformám, změnilo $\mathrm{v}$ Kremlu vnímání rizika plynoucího ze sovětského angažmá při změně východoněmeckého vedení. Objevovaly se zprávy, že pokud Honecker setrvá ve funkci, demonstranti se možná pokusí rozbořit Berlínskou zed. ${ }^{43}$ Gorbačov ovšem stále neprojevoval př́lišné nadšení nad tím, že by měl vyrazit do Berlína, aby pomohl těm, kteří organizovali odpor proti Honeckerovi. Teprve tehdy, když se mu dostalo ujištění, že bude mít možnost promluvit k vedení SED, se sovětské politbyro rozhodlo, že by Gorbačov měl cestu podniknout. ${ }^{44}$ Po př́letu do východoněmecké metropole pak pronesl srozumitelně adresovaný výrok, že život potrestá ty, kteř́ jednají př́liš pozdě, a tato jeho poznámka brzy pronikla na veřejnost. Ve stejném duchu varoval východoněmecké komunistické vedení, že stojí před zásadním rozhodnutím - bud’ se pohne směrem kupředu, anebo je čeká pád. Nepodpořil sice jednoznačně a výslovně plány těch členů vedení, kteří usilovali o nahrazení Honeckera, jeho apel na změnu nicméně pomohl celý proces uspíšit. Necelé dva týdny po Gorbačovově návštěvě tak Erich Honecker spolu se dvěma nejbližšími spolupracovníky rezignoval. O dva dny později obdržel Kreml poděkování od jeho nástupce za Gorbačovovu „p̌rátelskou podporu“..45

Jak se však ukázalo, tato podpora a změna ve východoněmeckém vedení, kterou umožnila, přišly př́liš pozdě. Stejně jako $v$ dalších případech, i tentokrát byl propočet možných rizik ze strany Kremlu chybný. Vycházel jednak z př́lišného optimismu ohledně výhledů východoněmeckého režimu do budoucnosti, jednak z př́lišné opatrnosti při zvažování rizika, že vlastním zasahováním do východoněmeckých událostí oslabí kontrolu SED nad jejich vývojem. ${ }^{46} \mathrm{~S}$ Moskvou v roli pouhého diváka dokázal Honecker blokovat reformy tak dlouho, až tlak společnosti přerostl do vlny protestů, které již nedokázalo zvládnout ani nové, pružnější vedení východoněmeckých komunistů.

43 Vypovídá o nich Čerňajevův záznam v diáři z 8.10.1989 (viz ČERŇAJEV, Anatolij: Sovmestnyj ischod: Dněvnik dvuch epoch. 1972-1991 gody. Moskva, Rosspen 2008, s. 806).

44 Tato informace pochází z rozhovoru autora s Anatolijem Čerňajevem (Moskva, 9.12.1997) a Valentinem Falinem (Moskevská oblast, 7.9.1998).

45 Vděčnost tlumočil Jakovlevovi východoněmecký velvyslanec v Moskvě Gerd Koenig (viz Zapis besedy A. N. Jakovleva s poslom GDR v SSSR G. Koenigom 20 oktjabrja 1989 g. In: JAKOVLEV, A. N. (ed.): Perestrojka, s. 363 - viz pozn. 24). Tehdejší vedoucí mezinárodního oddělení ÚV KSSS Valentin M. Falin se podle svých slov (v rozhovoru s autorem 7.9.1998) nedomníval, že by se byl Gorbačov jednoznačně vyjádřil, jaké kroky je třeba podniknout, aby došlo ke změně na špici SED.

46 Gorbačov zpětně přiznal, že vnímal reformní potenciál Honeckerova režimu poměrně optimisticky (viz GORBAČOV, M. S.: Poňat’ perestrojku... počemu eto važno sejčas. Moskva, Alpina Biznes Buks 2006, s. 215). Čerňajev měl však naprosto jasno v tom, že Honeckerův čas již dávno vypršel, což dokládá záznam v jeho diáři z 11.10.1989 (ČERŇAJEV, A.: Sovmestnyj ischod, s. 808 - viz pozn. 43 ). 


\section{Podpora spíše nástupu centristů než reformátorů}

Z podobné kombinace optimismu a opatrnosti vycházela tendence Kremlu podporovat po odstranění vysloužilých funkcionářủ spíše nástup centristů než radikálních reformátorů. V madarském př́ípadě Moskva ochotně podpořila Károlyho Grósze. Věrila, že Grósz, opatrný technokrat s naprostým nedostatkem představivosti, stojí na straně „zdravých sil“ $v$ Budapešti a že představuje jistější volbu než jeho proreformnější kolegové, jako například Rezső Nyers, Miklós Németh či Imre Pozsgay. ${ }^{47}$ Gorbačovovi se zamlouvala řada Pozsgayových návrhů reforem socialismu, měl však nadále obavy z rozkladného vlivu, který by mohl tento nekonformní politik mít na křehkou spolupráci, jež udržovala madarské vedení pohromadě. Jednota vládnoucí strany se zdála bezpečnější v rukou Grósze, v němž Kreml spatřoval silnou figuru, schopnou řídit umírněnou reformu, která by ukojila hlad po změnách, a zároveň by zachovala stabilitu. I když se na konci roku 1988 ukázalo, že tato očekávání byla až př́liš̌ optimistická, Moskva stále nejevila o Pozsgaye zájem. Při vzájemném setkání v Římě na jaře 1989 mu doporučil Alexandr Jakovlev, aby podporoval Grósze. Pozsgay se svou pověstnou prudkostí v reakci Jakovleva obvinil, že zůstává zajatcem stalinistického myšlení, jelikož zjevně raději jedná s agenty než se spojenci. ${ }^{48} \mathrm{Kreml}$ nicméně i potom zachovával př́zeň Grószovi, protože doufal, že dokáže spojit role silného muže a reformátora. Na počátku roku 1989 se zdálo, že rozdělení funkcí mezi Grósze jako předsedu komunistické strany a reformátora Németha jako předsedu vlády bylo nejlepší cestou k uskutečnění ŕízeného procesu změny, jak si to přál Kreml. Jakmile však Gorbačov zjistil, že Grósz ztrácí nad stranou kontrolu, odmítl cokoli podniknout na jeho podporu. ${ }^{49}$

Stejně jako v Budapešti, i v Berlíně se Kreml zdál nakloněn tomu, aby se vedení ujal centristický korunní princ. Moskva spatřovala v Egonu Krenzovi člověka, který je schopen vést Německou demokratickou republiku optimální cestou politicky fle-

47 Hodnocení Grósze obsahují memoáry Vadima Medveděva Raspad, s. 124 (viz pozn. 28). Gorbačovi̊v pohled na kliky v mad’arském vedení viz Iz vystuplenij na zasedaniji Politbjuro TsK KPSS 13 ijuňa 1986 goda. In: GORBAČOV, Michail S.: Sobranije sočiněnij, sv. 4. Moskva, Ves Mir 2008, s. 163.

48 Viz POZSGAY, Imre: Politikus-pálya a pártállamban és a rendszervaltásbán. Budapest, Püski 1993, s. 121 n. (citováno in: TOKES, Rudolf: Hungary's Negotiated Revolution: Economic Reform, Social Change and Political Succession, 1957-1990. Cambridge, Cambridge University Press 1996, s. 320). Podle Vadima Medveděva nebylo sovětské vedení s Pozsgayem v častém kontaktu (viz záznam rozhovoru Medveděva s autorem v Moskvě 10.12.1996).

49 Viz LEVESQUE, J.: The Enigma of 1989, s. 131 (viz pozn. 1). Tradicionalisté v mezinárodním oddělení UUV KSSS, jako např. Fjodorov, však stále preferovali Grósze a snažili se dát mu najevo podporu (viz Fragment notatki z rozmowy kierownika Wydziału Polityki Międzynarodowej KC KPCz M. Stefanaka z I zastępcą kierownika Wydziału Zagranicznego KC KPZR tow. R. Fiodorowem, 18 kwietnia 1989 r. In: DUDEK, Antoni - FRISZKE, Andrzej (ed.): Polska 1986-1989: Koniec systemu. Warszawa, Trio 2002, s. 267). 
xibilní a pokojné reformy pod vedením komunistické strany. ${ }^{50}$ Naděje vkládané do Krenze odrážely optimismus panující v Kremlu ohledně životaschopnosti honeckerismu bez Honeckera; v tvrdohlavosti starého muže byla spatřována hlavní překážka na cestě změn a dalšího vývoje. ${ }^{51}$ Tyto naděje přetrvaly i po pádu Berlínské zdi, jelikož Krenz projevil ochotu spolupracovat s lidmi, jako byl Hans Modrow. Kreml považoval Modrowa za slibného reformátora, a právě sovětská podpora přispěla $\mathrm{k}$ jeho jmenování předsedou východoněmecké vlády.

Sklon Moskvy opírat se raději o spolehlivé vůdce než podporovat reformátory se jasně projevil v př́padě Československa. Jelikož tato země figurovala na spodním konci žebříčku politicky nestabilních států, který si sestavil Kreml, v podpoře zdejších reformně orientovaných spojenců neměl spatřovat takové riziko. V boji o nástupnictví po Gustávu Husákovi však ani umírnění reformátoři, jako předseda vlády Lubomír Štrougal, nezískali jeho podporu, nebot mu záleželo v prvé řadě na schopnosti jednotlivých kandidátů zachovat jednotu ve vedení komunistické strany. ${ }^{52}$ Moskva byla proto ochotna spokojit se s konzervativnějším centristou Milošem Jakešem, jehož považovala za dostatečně houževnatého na to, aby udržel na uzdě zastánce tvrdé linie, a dostatečně pružného na to, aby uspokojil volání po změnách. ${ }^{53}$ Ani když se na jaře 1989 ukázalo, že Jakeš nedokáže udržet krok s tlakem na změny, Gorbačov mu nepřestal dávat najevo podporu. To si však český generální tajemník vyložil jako schvalování defenzivního př́stupu Prahy. ${ }^{54} \mathrm{Kreml}$ neudělal nic pro to, aby vyvinul na Jakeše větší tlak nebo aby povzbudil proreformně smýšlející členy československého vedení $\mathrm{v}$ jejich snaze Jakeše nahradit. ${ }^{55} \mathrm{~V}$ př́padě radikálnějších reformátorů spjatých s pražským jarem 1968, kteří prosazovali skutečnou perestrojku, zůstávala Moskva obzvláště opatrná. Ještě i v pozdním podzimu 1989,

50 Pozitivní hodnocení Krenze obsahují memoáry Vadima Medveděva (Raspad, s. 170 - viz pozn. 28) i Michaila GORBAČOVA (Žizň i reformy, sv. 2, s. 163 - viz pozn. 2). Viz rovněž ADOMEIT, H.: Imperial Overstretch, s. 418 a 420 (viz pozn. 40).

51 Viz GORBAČOV, M. S.: Poňat’ perestrojku..., s. 215 (viz pozn. 46).

52 To byla ústřední myšlenka Gorbačovových poznámek o změně v československém vedení v listopadu 1987 po návštěvě premiéra Ryžkova v Praze (viz Iz vystuplenij na zasedaniji Politbjuro TsK KPSS 19 nojabrja 1987 goda. In: GORBAČOV, M. S.: Sobranije sočiněnij, sv. 9, s. 29 (viz pozn. 33).

53 Viz MEDVEDĚV, V. A.: Raspad, s. 144 n. - viz pozn. 28 (v českém znění: PREČAN, V. (ed.): Svědectví o rozpadu „socialistického společenství", s. 537 n. - viz pozn. 2); GORBAČOV, M. S.: Žizň i reformy, sv. 2, s. 358 (v českém znění: PREČAN, V. (ed.): Svědectví o rozpadu „socialistického společenstvi“", s. 526 n.).

54 Viz JAKEŠ, Miloš: Dva roky generálním tajemníkem. Praha, Regulus 1996, s. 97; MEDVEDĚV, V. A.: Raspad, s. 108 n.

55 Hlavním kandidátem z této kategorie byl předseda vlády Ladislav Adamec, jeho nepř́mé náznaky však nenalezly v Moskvě odezvu (viz KREJČí, Oskar: Proč to prasklo, aneb Hovory o demokracii a „Sametové revoluci“. Praha, Trio 1991, s. 26 n.; viz rovněž LEVESQUE, J.: The Enigma of 1989, s. 178-181 - viz pozn. 1). 
kdy někteř́ konzervativci $\mathrm{v}$ Praze, $\mathrm{v}$ zoufalé snaze uchránit pozici komunistické strany, žádali Kreml, aby vynesl trumfovou kartu roku 1968 a pomohl jim tak změnit vedení strany a získat alespoň nějakou legitimitu v očích veřejnosti, zůstaly tyto žádosti bez odezvy. ${ }^{56}$ Optimistická víra v obrodný potenciál reformního komunismu byla zastřena opatrností. Formální sovětské přehodnocení událostí roku 1968 přišlo až v prosinci, kdy již bylo pro československé komunisty př́liš pozdě.

Optimismus spojený se sázkou na centristickou linii Moskvě vydržel zvláště dlouho v Polsku, kde trvale podporovala vládnoucího generála Wojciecha Jaruzelského. Jakožto strůjce výjimečného stavu, vyhlášeného v prosinci 1981, mohl být generál jen těžko považován za nejvíce proreformně smýšlejícího př́slušníka polské komunistické elity. Nebyl ani člověkem, který by měl největší potenciál získat podporu veřejnosti. Jaruzelski však disponoval kvalitami, které naplňovaly dvojí požadavek Kremlu - schopnost zachovat jednotu strany a stát $\mathrm{v}$ čele procesu řízené změny. Měl dostatečně silné postavení na to, aby mohl čelit zastáncům tvrdé linie, kteř́ odmítali jakékoli ústupky Solidaritě. A byl dostatečně pragmatický na to, aby učinil ústupky nezbytné $\mathrm{k}$ udržení pozice komunistické strany $\mathrm{v}$ čele změn. V ostře vyhroceném prostředí, které činilo z Polska nejvýbušnější zemi v celé východní Evropě, představoval nepoddajný, zároveň ale pragmatický centrista hodnotu, kterou byli v Moskvě ochotni vyvážit zlatem. Jaruzelski byl zároveň jediným východoevropským vůdcem, kterého Gorbačov skutečně respektoval a $\mathrm{k}$ němuž cítil určitou osobní náklonnost. ${ }^{57}$ Tato osobní důvěra vedla $\mathrm{k}$ tomu, že sovětský generální tajemník byl až přespř́liš optimistický, pokud šlo o generálovu schopnost zajistit obrodu polské komunistické strany a proces řízené reformy socialismu.

Kreml pohlížel na centristickou politiku nejoptimističtěji právě v Polsku a Madarsku - a právě $\mathrm{v}$ těchto zemích, kde reformy pokročily nejdále, se dočkal ve svém optimismu prvního zklamání. Zatímco předpokládal, že podporou centristů nejspíše povzbudí tamní komunistické strany $\mathrm{k}$ obrodě a pomůže jim udržet se v čele reformního procesu, v praxi byli centristé v Polsku i Madarsku smeteni radikálnějšími silami prosazujícími reformy. V konzervativnějších státech se silní centristé, podporovaní Moskvou, odhodlali k činům př́liš pozdě a udělali př́iliš málo pro to, aby odolali masivnímu tlaku, který nakonec vynesl k moci opoziční síly.

56 Viz MEDVEDĚV, V. A.: Raspad, s. 153 - viz pozn. 28 (v českém znění: PREČAN, V. (ed.): Svědectví o rozpadu „socialistického společenstvi“, s. 546 n.). Gorbačov odmítl návrh Šachnazarova, aby přehodnotil sovětský př́stup k roku 1968, jelikož by to mohlo oslabit Jakešovu pozici (viz záznam rozhovoru autora se Šachnazarovem v Moskvě 30.3.1998).

57 Viz GORBAČOV, M. S.: Žizň i reformy, sv. 2, s. 336-339, 344 n. a 351 (v českém znění: PREČAN, V. (ed.): Svědectví o rozpadu „socialistického společenstvi“", s. 520); MEDVEDĚV, V. A.: Raspad, s. 88. 


\section{Podpora „neoperestrojky“: vytváření koalic v socialistickém rámci}

Směsice nadějí a obav formovala rovněž př́stup Kremlu k politickým strategiím, jichž užívali centristé. Podobně jako u politického vůdcovství, i zde spojoval naději zejména $s$ těmi zeměmi, které dále pokročily na cestě reforem. Moskva se nadále vyhýbala tomu, aby vzbuzovala dojem, že vnucuje ostatním své priority. Michail Gorbačov neúnavně opakoval, že východoevropští vedoucí představitelé musí činit vlastní rozhodnutí. Ve strategických otázkách, narozdíl od problémů spojených s vůdcovstvím, však častěji projevoval své smýšlení. Dával zcela jasně najevo, že preferuje „neoperestrojkové“ kroky - tedy takové, které rozvíjely strategii integrace různých sil do politických koalic, jak se o to Gorbačov snažil na domácí scéně, $\mathrm{v}$ těch zemích východní Evropy, které výrazněji pokročily na cestě reforem. ${ }^{58}$

Podpora Kremlu umožnila vedoucím představitelům ve Varšavě a Budapešti snáze zaujmout „neoperestrojkovou“ linii. Jejich konzervativní kritici již naopak s podporou Sovětského svazu operovat nemohli. Gorbačovovo povzbuzování pomohlo posílit odhodlanost politického vedení v těchto zemích při prosazování kontroverzních a radikálních kroků, jako např́klad faktické legalizace polské Solidarity. $\mathrm{V}$ tomto směru rovněž přinesl užitek Gorbačovův souhlas s uplatněním strategie „kulatého stolu“, která umožnila do jednání zapojit jako partnery i opoziční skupiny. Strategie „kulatého stolu“ byla zcela jednoznačně ve shodě s Gorbačovovým preferováním smírilivého řešení politických konfliktů začleňováním opozičních sil do politického systému. Soulad mezi strategií „kulatého stolu“ a perestrojkou nepochybně způsobil, že sovětský vůdce byl nakloněn uplatnění radikálních postupů, k nimž se uchýlili komunisté v Mad’arsku a Polsku..$^{59}$

Méně často než o sympatiích Gorbačova se však hovoří o obavách, jež pocitoval z toho, že by strategie „kulatého stolu“ mohla nastartovat vývoj událostí, který by již překračoval hranice „neoperestrojky“. Obával se, že pokud by komunistické strany k radikálním krokům nepřistupovaly dost opatrně, mohly by podkopat svou vedoucí roli v procesu reforem, kterou Kreml nadále považoval za klíčovou. Gorbačov byl ochoten podpořit rozhovory u kulatého stolu jako pragmatický ústupek, který má za cíl zmírnit napětí a odvrátit krizi. Pouze hrozící krize v Polsku sovětského vůdce přiměla, aby přijal Jaruzelského plán vyjednávat se Solidaritou u kulatého stolu. To, co generál připravil a sovětský generální tajemník schválil, byla pragmatická strategie v duchu hesla „rozděl a panuj“, která měla rozštěpit Solidaritu na umírněné a radikály, a tak obnovit kontrolu nad událostmi. I v tomto př́padě se však Gorbačov obával, že proces vyjednávání u kulatého stolu může přinést neočekávané výsledky a že povolení voleb s účastí opozice, třebaže ne zcela svobodných,

58 „Neoperestrojkou“ zde rozumím reformní politické tendence v zemích východního bloku, které byly inspirovány sovětskou perestrojkou, avšak ve své hloubce a dalekosáhlosti překračovaly její hranice.

59 Tento bod zdůrazňuje Jacques Levesque v práci The Enigma of 1989, s. 115 n. (viz pozn. 1). 
může odstartovat řetězec událostí, které překročí vymezené „neoperestrojkové“ hranice „socialistické volby““. ${ }^{60}$

A opravdu, volby v červnu 1989 přinesly komunistům v Polsku potupnou porážku. Na červencovém setkání států Varšavské smlouvy Jaruzelski zcela otevřeně prohlásil, že Solidarita se žene polskou politickou krajinou jako tajfun. Poněkud zoufale dodal, že vplutí Solidarity jako štiky do politických vod může probudit komunistického kapra. Tyto naděje se ale ukázaly jako liché - morálka v Polské sjednocené dělnické straně i počet jejích členů zaznamenaly strmý pád. ${ }^{61}$ Polský debakl - Mad’aři přežili léto jen o něco málo lépe než jejich polští soudruzi - způsobil obrat v optimistickém smýšlení Kremlu o schopnostech východoevropských komunistických stran řídit reformní proces a udržovat vývoj v mezích vytyčených „neoperestrojkou“.

Navzdory neuspokojivým výsledkům těchto „neoperestrojkových“ strategií se ovšem Gorbačov vytrvale držel své politiky nevměšování. Tento nový principiální postoj se čím dál více stával jakýmsi ostrůvkem jistoty uprostřed stále prudší politické bouře. Rozhodnutí, jež přijímali komunističtí reformátoři v ostatních zemích, se Moskvě nejspíše ne vždy zamlouvala, ale Gorbačov nadále zastával názor, že každá země má právo zvolit si cestu, po níž se bude ubírat. A když se pak Kreml snažil přizpůsobit svou zahraniční politiku cestám, které si zvolily v roce 1989 Polsko a Mad’arsko, projevil i ochotu rozšíritit mantinely ohraničující proces „neoperestrojky“.

\section{Uvolňování omezení a předcházení konfliktům}

Od jara 1989 až do konce tohoto revolučního roku Kreml zmírnil dva klíčové požadavky, které dlouho svazovaly členy východního bloku - požadavek vlády komunistické strany a společné ochrany hranic. Moskva uvolnila omezení v těchto zásadních oblastech natolik, že vlastně došlo ke stržení dvou tradičních pilírů celého bloku. Tuto liberalizaci Moskva neprováděla tak aktivně, jako když propa-

60 Svědčí o tom Gorbačovovy komentáře během jeho setkání s Mieczysławem Rakowským v říjnu 1989 (Iz besedy s M. Rakowskim 21 oktabrja 1988 g. In: GORBAČOV, M. S.: Sobranije sočiněnij, sv. 12, s. 260 - viz pozn. 5; RAKOWSKI, M. F.: Dzienniki politicyzne 1987-1990, s. 268-275 - viz pozn. 22). O stejných obavách se sovětský vůdce zmínil při jednání se svými mad’arskými partnery, kteří připravovali zavedení systému více politických stran. Gorbačov schvaloval „socialistický pluralismus“ a ostentativně nereagoval na snahu premiéra Németha zlehčit rozdíl mezi pluralismem v systému s jednou stranou a systému s více stranami. Sovětský vůdce zdo̊razňoval, že je nutné udržet vývoj událostí na socialistické trajektorii. (Viz Record of Conversation between President M. S. Gorbachev and Miklos Nemeth, Member of the HSWP CC Politburo, Chairman of the Council of Ministers of the People's Republic of Hungary, Moscow, 3 March 1989. In: CWIHP Bulletin, č. 12-13 (2001), s. 76 n.)

61 Záznam Jaruzelského projevu na summitu Varšavské smlouvy 8.7.1989 viz Archiv Gorbačev-Fonda, fond 1, opis 1, Vstreča v uzkom sostave rukovoditělej bratskich partij stran-členov Varšavskogo dogovorja (zapis osnovnogo soděržanija vystuplenij), Bucharest, Rumynija. 
govala „neoperestrojkové“ reformy; spíše jen rezignovaně přijímala události a přizpůsobovala se jim. Gorbačov rozhodně nebyl spokojen $s$ mnoha změnami, jež se podle něj rozcházely s prioritami, které nadále považoval za klíčové. Nicméně, jak prohlásil v sovětském politbyru, rozčarování nad tím, co „prátelé“ dělají, se nesmělo stát záminkou pro moralizování a vměšování. ${ }^{62}$ Sovětský vůdce rozhodně nebyl potěšen vývojem událostí $\mathrm{v}$ Madarsku, kde vedení komunistické strany ztratilo kontrolu nad dèním a přepustilo rozhodující vliv

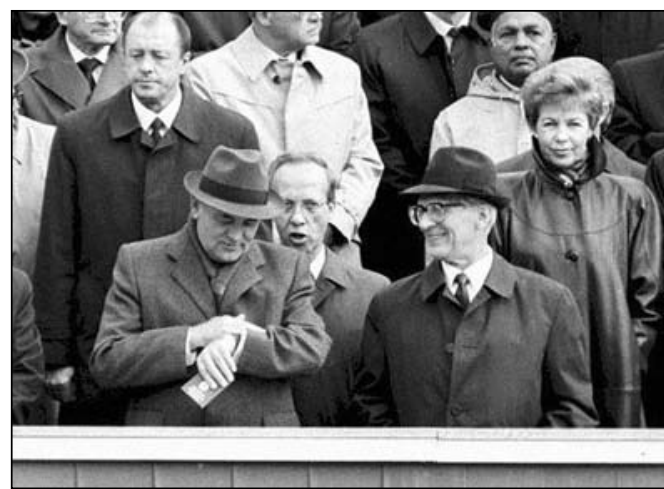

Symbolický okamžik při oslavách čtyřicátého výročí trvání Německé demokratické republiky koncem zárí 1989 ve východním Berlíně. Usmívající se Erich Honecker (1912-1994) netuší, že jeho vládě i státu odtikávají poslední dny radikálním reformátorům, kteří překročili hranice „neoperestrojky“. Gorbačov měl pochybnosti o veřejné rehabilitaci Imre Nagye jako národního hrdiny a madarských událostí na podzim 1956 jako národního povstání. Přesto zajistil, aby se Moskva nevměšovala do záležitostí, které vytrvale označoval za mad’arská rozhodnutí. ${ }^{63}$

Reakce na vývoj v Polsku se odvíjely podle podobné šablony. Kreml rozhodně nebyl spokojen, když v létě 1989 pozoroval, jak Lech Wałęsa rozbíjí svou silovou strategií na padrł Jaruzelského plány na velkou koalici pod vedením komunistů. Kromě několika kritických komentářů v sovětském tisku však Moskva nevyslovila žádnou námitku k vytvoření první nekomunistické vlády ve východním bloku. Jakmile se ukázalo, že Solidarita získala převahu, Moskva se rychle přizpůsobila nové politické realitě. Klíčoví členové sovětského vedení byli vysláni navázat „pracovni“" vztahy s novou vládou Tadeusze Mazowieckého. Moskva změnila své stanovisko a byla ochotna svolit

62 Gorbačovovy komentáře na jednání politbyra ÚV KSSS 13.4.1989 (V Politbjuro TsK KPSS..., s. 468 - viz pozn. 2).

63 Pozoruhodně malý odpor Kremlu vůči předem ohlašovaným mad’arským politickým změnám dokumentuje záznam o jednání Alexandra Jakovleva s madarským velvyslancem v SSSR Sándorem Rajnaiem z prosince 1988 (Zapis besedy A. N. Jakovleva s poslom VNR v SSSR S. Rajnai, 21 děkabrja 1988 g. In: JAKOVLEV, A. N. (ed.): Perestrojka, s. 290 n.). O pozdějších sovětských výhradách svědčí záznam jednání mezi Gorbačovem a mad’arským premiérem Némethem z 3.3.1989 (viz CWIHP Bulletin, č. 12-13 (2001), s. 77). Gorbačovovy údajné kroky k zamezení formálním stížnostem zmiňuje Jacques Levesque v práci The Enigma of 1989, s. 129 n. (viz pozn. 1). 
k tomu, že se vztahy s Varšavou přesunou z roviny propojení vládnoucích politických režimů do roviny odrážející státní zájmy. ${ }^{64} \mathrm{~K}$ podobnému procesu „normalizace“ vztahů došlo, když se nekomunisté dostali k moci v Československu a v NDR.

Sovětská ochota zmírnit základní požadavky na ideové a politické propojení se státy východní Evropy se zmenšovala, pokud šlo o bezpečnostní otázky. Kreml akceptoval realitu, že politické režimy $\mathrm{v}$ jednotlivých zemích regionu mohou být rozdílné, žádal ale po nových, nekomunistických vládách ujištění, že budou nadále plnit závazky plynoucí z jejich členství ve Varšavské smlouvě. Nové vlády byly více než připraveny tyto záruky poskytnout, jelikož si nikdo nebyl jist, zda se Kreml, který projevil bezpř́kladnou pružnost na politické frontě, bude chovat stejně i v bezpečnostních otázkách. Objevovaly se náznaky, že sovětské vedení by netolerovalo rozpad všech existujících bezpečnostních struktur. Nezdálo se, že by bylo připraveno smiŕit se s finlandizací celého regionu. Gorbačov tento dojem dále posiloval svými prohlášeními, že Sovětský svaz nebude trpně přijímat ohrožení své bezpečnosti, ale že se bude chovat tak, jak by se za daných okolností zachovala každá velmoc. ${ }^{65}$ Sovětský generální tajemník zcela jasně vysvětlil mad’arským vedoucím představitelům, že neutralita, po níž volali radikálové v Budapešti, je jednoduše nerealistická. Madaři, jak dodal, by se spíše měli soustř̌edit na využití rozšířené národní autonomie v rámci modernizující se Varšavské smlouvy. ${ }^{66} \mathrm{~V}$ tomto směru vyslala Moskva ke svým spojencům některé povzbudivé signály. Návrh z prosince 1988 jednostranně snížit stavy sovětských vojsk rozmístěných v zemích východní Evropy byl součástí obecněji pojímané, i když stále podmíněné, ochoty zvážit stažení všech ozbrojených sil z regionu, po němž některé východoevropské státy stále silněji volaly. ${ }^{67}$

64 Ministr zahraničí Eduard Ševardnadze, ministr obrany Dmitrij Jazov, předseda KGB Vladimir Krjučkov a Alexandr Jakovlev vypracovali 20.9.1989 zprávu o situaci v Polsku, další postup byl diskutován a stanoven na jednání sovětského politbyra 28. září (viz Hoover Institution Archives, fond 89 (Communist Party of the Soviet Union on Trial), kotouč 1991, sekce 9, dokument 33, Ob obstanovke vo Polše, vozmožnych varjantach jejo rozvitija, perspektivach sovetsko-polskich otnošenij (10 stran)).

65 Archiv Gorbačev-Fonda, fond 1, opis 1, Zapis besedy M. S. Gorbačeva s pervym sekretarjem TsK POPR M. Rakowskim (Polša), 11 oktabrja 1989 g., s. 22; viz rovněž RAKOWSKI, M. F.: Dzienniki politicyzne 1987-1990, s. 551 (viz pozn. 22). Podle zpráv, které dorazily do Varšavy, prohlásil Medveděv v Berlíně, že Moskva není připravena přijmout finlandizaci (tamtéž, s. 533).

66 Zpráva Károlyho Grósze pro politbyro MSDS o jednáních s Gorbačovem ve dnech 23.24.3.1989 je citována in: BÉKÉS, Csaba: Back to Europe: The International Background of the Transition in Hungary, 1988-1990, s. 15 (http://www.coldwar.hu/html/en/publications/ roundtables-bekes.htm).

67 Madaři byli v této otázce nejupřímnější (viz Zapis besed s rukovodstvom VNR - K. Grosom, Ja. Berentsem, M. Nemetom, M. Sjurošem, 10-11 nojabrja, 1988 g. In: JAKOVLEV, A. N. (ed.): Perestrojka, s. 254 n.). Celá otázka škrtů v armádě, včetně jednotek rozmístěných ve východní Evropě, byla diskutována ze zcela nového úhlu pohledu na schůzi sovětského politbyra 3.11.1988. Dokládá to zápis v deníku Anatolije Čerňajeva z 3.11.1988 (ČERŇAJEV, A.: Sovmestnyj ischod, s. 770 n. - viz pozn. 43). 
Dojem, že Kreml je ochoten akceptovat větší míru národní autonomie v bezpečnostní oblasti, dále posilovala jeho nově projevovaná flexibilita v otázce hraničního režimu. Důležitá rozhodnutí ohledně hraničního režimu byla v praxi, když už ne teoreticky, vždy výsadou Moskvy. Hranice východního bloku totiž vlastně představovaly vnější limity sovětského prostoru. $V$ druhé polovině roku 1989 však Moskva zmírnila omezení i v této velice citlivé oblasti. Ponechala na úvaze Budapešti, zda uvolnit hraniční kontroly na přechodech s Rakouskem a tak umožnit tisícům východních Němců, aby využili této cesty $\mathrm{k}$ úniku do Spolkové republiky. A co bylo obzvlášṫ důležité, Moskva přijala bez viditelnějších protestů opatření východoněmeckých úřadů, jež umožňovala volný průchod zdí rozdělující Berlín. V obou př́padech zaujala Moskva stanovisko, že se jedná o záležitosti, o nichž musejí rozhodnout př́mo zainteresované národní vlády.

Jak si vysvětlit ochotu Moskvy smírit se tak snadno se změnami, které východoevropané provedli v politickém uspořádání a hraničních režimech? I v tomto př́ípadě se do úvah Moskvy promítal optimismus, byt spíše okrajově. I po neúspěších polských komunistů se někteří členové sovětského politbyra domnívali, že ekonomické a sociální problémy spojené s vládnutím v Polsku mohou probudit prvky socialismu v rámci Solidarity a tak př́znivě ovlivnit povahu nového režimu. Zpráva vypracovaná vysokými sovětskými úředníky si pohrávala se spekulacemi o možnosti socialistické demokracie švédského typu, která by se v Polsku mohla výhledově vytvořit. ${ }^{68}$ Gorbačovův tým si udržoval neochvějný optimismus ohledně šancí socialistické levice $v$ Německé demokratické republice na úspěch, a to až do její volební porážky v březnu 1990. ${ }^{69}$ Obecně lze říci, že Moskva se smírila s tím, že bude muset jednat s nekomunistickými vládami, a zároveň začala razit myšlenku, že konec vlády komunistických stran nemusí nutně znamenat konec socialismu ve východní Evropě.

Zatímco Kreml se jako tonoucí držel svých stébel optimismu, k vyrovnání se změnami režimů ve východní Evropě mu dopomohly především obavy, které pocitoval. Hlavní motivační silou zde byl strach z toho, že by pokusy Moskvy či místních komunistů brzdit probíhající změny mohly dále zvýšit nestabilitu a vést ke konfliktu. Snaha vyhnout se konfliktům byla nejsilnějším faktorem, který se promítal do ochoty Moskvy vyrovnat se i s negativními změnami a postupně uvolňovat tradiční omezení. Pragmatická snaha udržovat stabilitu dále posilovala Gorbačovův

68 Viz Hoover Institution Archives, fond 89 (Communist Party of the Soviet Union on Trial), kotouč 1991, sekce 9, dokument 33, Ob obstanovke vo Polše, vozmožnych varjantach jejo rozvitija, perspektivach sovetsko-polskich otnošenij.

69 Tato důvěra ve východoněmeckou levici se odrazila i v neformální diskusi o německých otázkách vedené na vysoké úrovni 26.1.1990 (viz Obsužděnije germanskogo voprosa na uzkom soveščaniji v kabinětě geněralnogo sekretarja TsK KPSS, 26 janvarja 1990 goda. In: V Politbjuro TsK KPSS..., s. 551-555 - viz pozn. 2). 
principiální odpor ke konfrontacím a k užití síly. Ohromná snaha, kterou Moskva vyvinula, aby zabránila jakýmkoli násilným řešením, jež by mohla vyvolat konflikt, byla tedy nejdůsledněji uplatňovaným a nejvýznamnějším trendem sovětské politiky v těchto letech rychlé transformace východní Evropy.

V kritických okamžicích let 1989 a 1990 Moskva varovala východoevropské komunistické vůdce, aby nepodlehli pokušení uchýlit se při jednáních s opozicí a při zvládání protestů $\mathrm{k}$ užití síly. ${ }^{70}$ Jedním z důvodi̊, proč se Gorbačov zdráhal postavit proti rehabilitaci mad’arských vůdců z roku 1956, byla obava, že kritika ze strany Sovětského svazu by mohla povzbudit zastánce tvrdé linie v Budapešti k použití násilí proti demonstrantům. Když v srpnu 1989 dočasně hrozilo, že se vůdce polských komunistů Mieczysław Rakowski odmítne připojit k vládě Solidarity, Gorbačov ho nabádal, aby zaujal konstruktivní stanovisko. O dva měsíce později ve Varšavě varoval vedoucí představitele poražené komunistické strany před bojovností, nebot' se obával, že by konfrontace s opozicí mohla vyústit v konflikt, a polskou politiku vnímal jako nebezpečný sud se střelným prachem. ${ }^{71}$ Tyto obavy byly rovněž důvodem pro podobně formulovaná varování adresovaná zle tísněným komunistům v Československu. V říjnu a listopadu 1989 Moskva dala jasně najevo východoněmeckým představitelům své očekávání, že dokáží řešit narůstající vlnu protestů tak, aby byl zajištěn nenásilný vývoj dalších událostí. ${ }^{72}$

Snaha rozptýlit napětí, které by mohlo vést ke konfliktu, stála do značné míry rovněž za ochotou Moskvy uvolnit některá omezení v hraničním režimu a dovolit tak Budapešti a východnímu Berlínu provést v této oblasti zásadní změny. V březnu 1989 Gorbačov premiérovi Miklósi Némethovi zcela jasně naznačil, že Moskva nemá žádné výhrady k mad’arským plánům zmírnit a posléze zcela zrušit omezení na hranicích s Rakouskem..$^{73}$ Mad’aři považovali tento přístup Moskvy za principiální souhlas se změnou svého hraničního režimu a zjevně již nežádali o konkrétně formulované schválení pro rozebrání bariér na hranici s Rakouskem v srpnu téhož roku. Zároveň se však snažili zjistit, jak se bude Moskva obecně stavět $\mathrm{k}$ jejich záměru dovolit východoněmeckým „turistům“ v Mad’arsku použít nově otevřených přechodů jako únikové cesty do Spolkové republiky. Sovětské ministerstvo

70 Viz KRAMER, Mark: Gorbachev and the Demise of East European Communism. In: PONS, Silvio - ROMERO, Federico (ed.): Reinterpreting the End of the Cold War. London, Cass 2004, s. $188-192$.

71 Gorbačovovy poznámky na jednání politbyra 12.10.1989 jsou zachyceny v publikaci $V$ Politbjuro TsK KPSS..., s. 516.

72 Viz GORBAČOV, M. S.: Žizň i reformy, s. 163 (viz pozn. 2); ADOMEIT, H.: Imperial Overstretch, s. 363 n. (viz pozn. 40).

73 V reakci na Némethovu zprávu o plánech zrušit omezení na hranici s Rakouskem do roku 1991 Gorbačov pouze poznamenal, že sovětský hraniční režim se více otevírá (Archiv Gorbačev-Fonda, fond 1, opis 1, Zapis besedy M. S. Gorbačeva s členom TsK VSRP Predsedatělem Sovjeta Ministrov VNR Miklosem Nemetom (Vengrija), 3 marta 1989g, s. 13 n.). 
zahraničí nevyslovilo ani v tomto směru žádné námitky a Madarům sdělilo, že tuto záležitost musejí vyřešit oni a východní Němci. ${ }^{74}$

Za zdrženlivým, odtažitým přístupem Moskvy $\mathrm{k}$ těmto citlivým otázkám byly v zásadě dvě úvahy. Obě plynuly ze snahy o zmírnění napětí, které by mohlo vyvolat nestabilitu v Německé demokratické republice a přilehlém okolí. Kremlu se $\mathrm{v}$ prvé řadě zamlouvala představa, že změny $\mathrm{v}$ mad’arské hraniční politice mohou zvýšit tlak na vedení východoněmeckých komunistů a přinést jeho výměnu, kterou Moskva i Budapešt považovaly již dlouho za potřebnou. Neochota Kremlu vměšovat se do východoněmecké politiky způsobila, že byl tím více nakloněn jiným krokům, které mohly uspíšit mocenskou rošádu ve východním Berlíně a uvolnit cestu tolik potřebným reformám. Kreml však hlavně doufal, že otevření cesty tisícům východoněmeckých „turistư“ na Západ přes Mad’arsko poslouží jako bezpečnostní ventil, který zmírní tlak ze strany veřejnosti, jenž by mohl $\mathrm{v}$ opačném př́padě vyvolat rozklad v celé středovýchodní Evropě.

Podobné snahy uklidnit výbušnou situaci a vyhnout se konfliktu vysvětlují uvolněný př́stup Moskvy $\mathrm{k}$ liberalizaci východoněmeckých cestovních zákonů a její takřka bezstarostné přijetí otevření hranice $\mathrm{v}$ Berlíně. ${ }^{75}$ Moskva nebyla předem informována o načasování a přesné podobě opatření, která měla umožnit volný pohyb mezi oběma částmi města. Mnozí činitelé v Kremlu považovali zprůchodnění Berlínské zdi za přijatelné a někteř́, jako např́íklad ministr zahraničí Eduard Ševardnadze, $v$ něm dokonce spatřovali pozitivní krok z hlediska dodržování lidských práv a dosažení politické stabilizace. ${ }^{76}$ Na začátku listopadu 1989 Michail Gorbačov novému prvnímu tajemníkovi Jednotné socialistické strany Německa Egonu Krenzovi jasně sdělil, že Moskva podporuje liberalizaci cestovních zákonů a hraničního režimu v NDR, pokud tyto změny pomohou snízit riziko konfliktu. Když se Krenz konkrétně zmínil o tom, že nepokoje u Berlínské zdi by mohly vést $\mathrm{k}$ vyhlášení výjimečného stavu, sovětský vůdce ho nabádal, aby se snažil za každou cenu zabránit podobnému vývoji. ${ }^{77}$ Vzhledem ke vzrůstajícímu tlaku veřejnosti na

74 Ševardnadzeho blízký spolupracovník Stěpanov v rozhovoru s autorem v Moskvě 31.3.1998 uvedl, že předseda madarských komunistů Károly Grósz toto rozhodnutí zdůvodňoval snahou o zmírnění napětí. Viz rovněž LEVESQUE, J.: The Enigma of 1989, s. 153 (viz pozn. 1); SEBESTYEN, Viktor: Revolution 1989: The Fall of the Soviet Empire. London, Weidenfeld \& Nicolson 2009, s. 258.

75 Viz užitečné shrnutí a dokumenty v práci: HERTLE, Hans-Hermann: The Fall of the Wall: The Unintended Self-Dissolution of East Germany's Ruling Regime. In: CWIHP Bulletin, č. 12-13 (2001), s. 131-164, zvláště s. 138 n.

76 Svědčí o tom poznámky na jednání politbyra ÚV KSSS 3.11 .1989 (viz V Politbjuro TSK KPSS..., s. 524 - viz pozn. 2). O tom, že Moskva nebyla informována v předstihu, psal Igor Maxymičev $\mathrm{v}$ listu Nězavisimaja gazeta 12.11.1993.

77 Viz Beseda M. S. Gorbačeva s E. Krenzem, 1 nojabrja 1989 goda. In: GALKIN, Alexandr - ČERŇAJEV, Anatolij (ed.): Michail Gorbačev i germanskij vopros: Sbornik dokumentov 1986-1991. Moskva, Ves Mir 2006, s. 243. 
další uvolnění cestování na Západ se zprůchodnění zdi jevilo jako prozíravý krok nejen vedoucím činitelům ve východním Berlině, ale také v Moskvě. I v situaci, kdy obavy Kremlu postupně narůstaly, někteří sovětští představitelé nadále doufali, že tento ústupek požadavkům veřejnosti nastolí politické klima, které bude př́íznivější pro obrodu východoněmecké komunistické strany a „neoperestrojkové“ reformy, což by mohlo přispět ke stabilizaci NDR a k posílení jejího postavení při vyjednávání o užších vztazích se Spolkovou republikou. ${ }^{78}$

Tyto naděje vkládané do životaschopnosti strategicky nejdůležitějšího státu v oblasti východní Evropy neodrážely pouze přetrvávající optimismus v Kremlu. Byly zároveň znamením jeho rostoucí víry v potenciál spolupráce se Západem ve východoevropských záležitostech.

\section{Proměna vnímání politiky Západu vůči východní Evropě}

Není možné plně objasnit právě nastíněné trendy sovětské politiky, aniž bychom alespoň zběžně odkázali na celkový kontext měnících se vztahů se Západem. Je obtížné pochopit pozoruhodně tolerantní, téměř povolný př́istup Moskvy $\mathrm{k}$ otřesům ve východní Evropě počínajícím druhou polovinou roku 1989, aniž bychom vzali v potaz narůstající intenzitu komunikace a porozumění mezi Moskvou a Západem. Od roku 1988 se výrazně zvýšila míra důvěry Moskvy vůči Západu obecně, zvláště pak ve vztazích se západoevropskými státy; důvěra vǔči Washingtonu narůstala pomaleji. V létě a na podzim 1989 začínal Kreml věřit, že západní představitelé si přejí spíše úspěch než neúspěch perestrojky. Bylo pro něj tedy snazší nazírat na vzrůstající roli Západu ve východní Evropě neutrálně, či dokonce kladně. Během období perestrojky se Kreml čím dál více smiřoval se stoupající hospodářskou a politickou angažovaností Západu ve východní Evropě.

V tomto stále smiŕlivějším přístupu Moskvy k významnější roli Západu v této oblasti byl př́tomen i silný ekonomický motiv. Kreml považoval hospodářské problémy za zásadní důvod krize v regionu. Na počátku roku 1989 věřil, že některé zdejší státy stojí na pokraji bankrotu, zejména kvưli míre jejich zadlužení vưči Západu.79 Již předtím, než situace dospěla do této krizové fáze, však Kreml dospěl k závěru, že ani nejohroženějším zemím nemůže výrazněji pomoci. Gorbačov pravidelně odmítal jejich žádosti o pomoc s poukazem na nedostatek zdrojů. Neblahý stav sovět-

78 Viz GORBAČOV, M. S.: Žizň i reformy, s. 163 (viz pozn. 2); MODROW, Hans: Vzljot i paděnije. In: MAXYMIČEV, I. (ed.): Poslednij god GDR, s. 173 (viz pozn. 40).

79 Svědčí o tom zpráva Georgije Šachnazarova z října 1988 (viz Cena svobody, s. 367-369) a memorandum mezinárodního oddělení ÚV KSSS pro Alexandra Jakovleva z února 1989 (viz CWIHP Bulletin, č. 12-13 (2001), s. 62-68). Polský dluh vůči Západu se zvýšil z 26,9 miliard dolarů v roce 1984 na 38,9 miliard dolarů v roce 1988; celkové zadlužení RVHP na Západě se ve stejném období zvýšilo z 87,6 miliard dolarů na 140,5 miliard dolarů (viz GAJDAR, Jegor: Gibel imperiji: Uroky dlja sovremennoj Rossiji. Moskva, Rosspen 2004, s. 224). 
ského hospodářství jasně naznačoval, že si Kreml nemůže nadále dovolit vyplácet, či dokonce navyšovat dotace chřadnoucím východoevropským státům..$^{80}$

Již na počátku roku 1989, možná dokonce i dřive, se Kreml smíril se skutečností, že klíčové východoevropské státy, jako např́íklad Polsko či Madarsko, budou muset požádat Západ o nový splátkový harmonogram a další úvěry, pokud nechtějí sklouznout ještě hlouběji do krize. Na schůzi sovětského politbyra krátce před pádem Berlínské zdi Gorbačov poznamenal, že pouze hospodářská pomoc ze Spolkové republiky může pomoci Východnímu Německu udržet se nad vodou. ${ }^{81}$

Větší závislost východní Evropy na Západě se stala pro Moskvu přijatelnější díky tomu, že změnila svi̊j pohled na americkou a západoevropskou politiku v oblasti. V první polovině roku 1989 už nenahlížela na úmysly Západu ve východní Evropě tak negativně. Až do konce roku 1988 přitom vedoucí sovětští představitelé stále kritizovali obzvláště americkou politiku jako podvratnou činnost a vměšování. Gorbačov se domníval, že se americký velvyslanec v Budapešti chová jako Gauleiter a že Washington svými neohrabanými způsoby připomíná slona v porcelánu. ${ }^{82}$ Pohled Moskvy na roli Západu, zejména západní Evropy, se oproštoval od této kritičnosti teprve od konce roku 1988. V listopadu 1988 se britská premiérka Margaret Thatcherová při své návštěvě Polska ovládla, nevyzvala $\mathrm{k}$ boji proti komunistům a místo toho poučovala představitele Solidarity o nutnosti zvolit spíše opatrnou než bojovnou taktiku. Dokonce i roli Spojených států Moskva postupně přehodnocovala $\mathrm{v}$ důsledku překvapivě zdrženlivého a konstruktivního př́stupu prezidenta George Bushe během jeho návštěvy Polska a Madarska v červenci 1989. I když některé věci v chování amerického prezidenta Gorbačova a jeho tým stále rozčilovaly, ocenili Bushovo vyjádření podpory Wojciechu Jaruzelskému a výzvy k zachování rozvahy adresované Solidaritě..$^{83}$

Zatímco se letní politická krize na podzim prohlubovala a dále se šírila východní Evropou, Gorbačovův tým začal pohližet na západní představitele spíše jako na potenciální partnery při stabilizaci poměrů než jako na podvratné konkurenty. Rovněž začalo být zřejmé, že je v zájmu Moskvy brát Spojené státy a západoevropské země jako partnery, kteří se nebudou vměšovat do záležitostí sovětského „blízkého pohraničí‘. Jejich spolupráce přitom nebyla důležitá pouze ve východní Evropě,

80 Viz např. Beseda M. S. Gorbačeva s E. Krenzem, 1 nojabrja 1989 goda. In: GALKIN, A. - ČERŇAJEV, A (ed.): Michail Gorbačev i germanskij vopros, s. 239 (viz pozn. 76).

81 Záznam z jednání politbyra ÚV KSSS 3.11.1989 je přetištěn v publikaci $V$ Politbjuro TSK KPSS..., s. 524 (viz pozn. 2).

82 Archiv Gorbačev-Fonda, fond 1, opis 1, Iz besedy s premjer-ministrom Indiji Radživom Gandi, 15 ijulja 1989 goda.

83 Ševardnadzemu se údajně Bushovo chování líbilo (viz MATLOCK, Jack F: Autopsy on an Empire: The American Ambassador's Account of the Collapse of the Soviet Union. New York, Random House 1995, s. 199). 
ale snad ještě více v kontextu narůstající nestability v západních svazových republikách samotného Sovětského svazu. ${ }^{84}$

Kreml nepodléhal iluzím, že by představitelé Západu, kteří nyní varovali před bojovností a propagovali výhody politického kompromisu, náhle přestali prosazovat své vlastní zájmy. Gorbačovův tým však věril, že úspěch při budování větší důvěry ve vztahu se Západem může v obecné rovině přispět k proměně vzájemného střetávání zájmů v regionu z nekooperativní hry s nulovým součtem na kooperativní hru s nenulovým součtem. Optimistické vnímání pokroku v širším kontextu vztahů mezi Východem a Západem pomáhalo Moskvě akceptovat radikální reformy, změny režimů, a dokonce částečné posuny ve spojeneckých vazbách jednotlivých členů východního bloku. Gorbačovovi tento jeho optimistický pohled v širším měřítku umožňoval důvěřovat ujištování západních politiků, že se zdrží všech kroků, které by mohly destabilizovat křehkou situaci v regionu, zvláště pak v Německé demokratické republice. I když byl sovětský vůdce zklamán některými neočekávaně asertivními kroky - zejména desetibodovým plánem spolkového kanclére Helmuta Kohla na sjednocení Německa - nadále považoval západní představitele za potenciální partnery s nepředstíraným zájmem o stabilizaci poměrů. Gorbačovi̊v tým chtěl věrit, že prosincový sovětsko-americký summit na Maltě dále posílil již dříve poskytnuté záruky Washingtonu, že nevyužije současnou krizi na úkor sovětských zájmů.

Ke konci roku 1989 Gorbačovův tým viděl v Západu spíše stabilizující než konkurenční sílu ve východní Evropě. ${ }^{85}$ Toto převážně pozitivní vnímání Západu umožnilo Gorbačovovi udržovat si velice dlouho optimismus, pokud šlo o šanci přetvořit Varšavskou smlouvu v politickou alianci, která by nakonec mohla posloužit jako výchozí platforma pro sbližení s političtěji profilovanou Severoatlantickou aliancí. Prohlubující se sklíčenost, kterou východní Evropa na přelomu let 1989 a 1990 v Moskvě vyvolávala, tedy doprovázely i záblesky naděje, a to až do poslední chvíle.

$$
* * *
$$

Posouzení Gorbačovovy východoevropské politiky samozřejmě závisí na zvolených kritériích. Je-li tehdejší sovětská politika poměřována jako ucelený soubor jasně definovaných cílů a dobře promyšlených strategií, bude její hodnocení spíše negativní. Sovětské reakce na vývoj v regionu vycházely z nápaditých vizí a principů. Téměř zcela však chyběly realistické strategie, které by umožnily Moskvě

84 Viz Zapis besedy A. N. Jakovleva s poslom SŠA v SSSR J. Matlokom, 20 ijulja 1989. In: JAKOVLEV, A. N. (ed.): Perestrojka, s. 341 (viz pozn. 24). Gorbačov chválil také zodpovědný př́istup francouzského prezidenta Françoise Mitterranda na setkání obou státníků 4.7.1989.

85 Tento pocit důvěry jasně vystupuje na povrch v Čerňajevově podrobném popisu a zhodnocení summitu na Maltě, jak je patrné ze zápisu v jeho deníku 10.12.1989 (ČERŇAJEV, A.: Sovmestnyj ischod, s. 822-824, 826 a 828 - viz pozn. 43). 
naplnit tyto vizionářské cíle $s$ prostředky, které měla k dispozici. Její hodnocení situace $\mathrm{v}$ jednotlivých zemích bylo $\mathrm{v}$ převážné většině případů nepřesné, informace o tamní politice neúplné, koordinace špatná a reakce improvizované. Toto měřítko je však př́lišs př́sné, chceme-li je vztáhnout na situaci, kdy byla většina aktérů, včetně těch na Západě i ve východní Evropě, zaskočena rozsahem i rychlostí změn. Je nutno rovněž vzít v potaz, že Kreml byl v politické oblasti nepochybně přetížen, jelikož se snažil přetvořit vnitropolitický systém a zároveň dosáhnout změny svých zahraničněpolitických vztahů.

Z hlediska Gorbačovových vlastních vizí a principů byla jeho východoevropská politika, spočívající v přizpo̊sobení se a podpoře vývoje v oblasti, minimálně z poloviny úspěšná. V reformně pokročilejších státech napomohla obrodě komunistických stran a vytváření politických koalic. Řadu věcí mohl nepochybně Kreml udělat lépe. Jeho strategie byla nedomyšlená z hlediska prosazování sovětských národních zájmů. Mohl podniknout více kroků na podporu reformátorů v konzervativnějších zemích východní Evropy a k odstranění vysloužilých funkcionářơ blokujících změny. Skutečnost, že reformní komunisté prohráli ve většině států v souboji s radikálnější politickou opozicí, nebyla však primárně důsledkem politiky Moskvy, ale spíše vyplývala z místních podmínek. Tam, kde se progresivně zaměření místní vưdci snažili o prosazování reforem, byl Gorbačovův optimismus příliš velký, i když ne zcela neopodstatněný. Vývoj, který je dnes zpětně vnímán jako nevyhnutelný, byl tehdy mnoha lidmi považován za nejistý a závislý na řadě okolností. Většinou přinesl výsledky, které si Gorbačovův tým nepřál, či dokonce ani neočekával. Způsob, jakým se změny odehrály, nicméně velice úzce souzněl s některými klíčovými principy Gorbačovovy politiky, zejména s odmítáním intervence a užití síly. Právě tyto principy pak utvářely v rozhodujících okamžicích přístup Kremlu k vývoji ve východní Evropě. Přijetí radikálních změn, podpora politických kompromisů a odpor vi̊či donucovacím metodám ze strany Moskvy, to vše významně ovlivnilo zpơsob, jakým se změny odehrály. Skutečnost, že hekticky prováděné revoluční změny, které proměnily politickou mapu východní Evropy, měly takto mírumilovný průběh, byla do značné míry zásluhou Gorbačovovy politiky. 